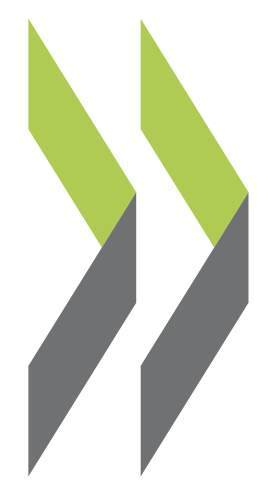

OECD Economics Department Working Papers No. 1389

Making income and property taxes more growth-friendly and redistributive in India

\section{Isabelle Joumard,}

Alastair Thomas,

Hermes Morgavi 


\section{Unclassified}

ECO/WKP(2017)21

Organisation de Coopération et de Développement Économiques

Organisation for Economic Co-operation and Development

02-Jun-2017

ECONOMICS DEPARTMENT

English - Or. English

\section{MAKING INCOME AND PROPERTY TAXES MORE GROWTH-FRIENDLY AND REDISTRIBUTIVE IN INDIA}

ECONOMICS DEPARTMENT WORKING PAPERS No. 1389

By Isabelle Joumard, Alastair Thomas and Hermes Morgavi

OECD Working Papers should not be reported as representing the official views of the OECD or of its member countries. The opinions expressed and arguments employed are those of the author(s).

Authorised for publication by Alvaro Pereira, Director, Country Studies Branch, Economics Department.

All Economics Department Working Papers are available at www.oecd.org/eco/workingpapers

JT03415233

Complete document available on OLIS in its original format

This document, as well as any data and map included herein, are without prejudice to the status of or sovereignty over any territory, to the delimitation of international frontiers and boundaries and to the name of any territory, city or area. 
OECD Working Papers should not be reported as representing the official views of the OECD or of its member countries. The opinions expressed and arguments employed are those of the author(s).

Working Papers describe preliminary results or research in progress by the author(s) and are published to stimulate discussion on a broad range of issues on which the OECD works.

Comments on Working Papers are welcomed, and may be sent to OECD Economics Department, 2 Rue André-Pascal, 75775 Paris Cedex 16, France, or by e-mail to eco.contact@oecd.org.

All Economics Department Working Papers are available at. www.oecd.org/eco/workingpapers

This document and any map included herein are without prejudice to the status of or sovereignty over any territory, to the delimitation of international frontiers and boundaries and to the name of any territory, city or area.

The statistical data for Israel are supplied by and under the responsibility of the relevant Israeli authorities. The use of such data by the OECD is without prejudice to the status of the Golan Heights, East Jerusalem and Israeli settlements in the West Bank under the terms of international law.

Latvia was not an OECD Member at the time of preparation of this publication. Accordingly, Latvia does not appear in the list of OECD Members and is not included in the zone aggregates.

\section{(C) OECD (2017)}

You can copy, download or print OECD content for your own use, and you can include excerpts from OECD publications, databases and multimedia products in your own documents, presentations, blogs, websites and teaching materials, provided that suitable acknowledgment of OECD as source and copyright owner is given. All requests for commercial use and translation rights should be submitted to rights@oecd.org 
ECO/WKP(2017)21

\section{ABSTRACT/RÉSUMÉ \\ Making income and property taxes more growth-friendly and redistributive in India}

Tax reforms are crucial to promoting inclusive growth in India. The replacement of a myriad of consumption taxes by a Goods and Services Tax (GST) will boost India's competitiveness, investment, job creation and tax compliance. The potential to raise additional revenue from taxes on goods and services is however limited. In contrast, reforming income and property taxes should help to i) raise more revenue to finance much needed social and physical infrastructure while keeping public debt under control; ii) reduce inequality by increasing the redistributive effect of taxation; iii) promote productivity by reducing distortions in the allocation of resources which emanate from the corporate income tax; iv) boost job creation by eliminating the bias against labourintensive activities; v) promote confidence, and thus investment, by improving clarity and certainty regarding tax rules and their application and vi) reinforce the ability of states and municipalities to provide key public infrastructure and services. This paper presents the main characteristics of the tax system as well as the rationale and options for reform.

JEL codes: $\mathrm{H} 20, \mathrm{H} 24, \mathrm{H} 25, \mathrm{H} 26, \mathrm{H} 71$

Keywords: India, tax system, income tax, property tax, inheritance tax, tax administration, base erosion and profit shifting

$$
* * * * *
$$

\section{Impôts sur le revenu et sur la propriété : les rendre plus propices à la croissance et en accentuer le caractère redistributif}

Les réformes fiscales sont essentielles pour renforcer la croissance inclusive. Le remplacement de nombreuses taxes à la consommation par une taxe sur la valeur ajoutée (Goods and Services Tax) va promouvoir la compétitivité, l'investissement, la création d'emplois et le respect des règles fiscales. En revanche, il ne devrait pas se traduire par une augmentation des recettes fiscales. Une réforme des impôts sur le revenu et sur la propriété pourrait: i) accroître les recettes fiscales et ainsi financer les besoins en infrastructures physiques et sociales tout en maintenant le niveau de la dette publique sous contrôle ; ii) réduire les inégalités en augmentant l'effet redistributif de l'impôt ; iii) engendrer des gains de productivité en réduisant les distorsions dans l'allocation des ressources inhérentes aux impôts pesant sur les entreprises; iv) promouvoir la création d'emplois en éliminant le biais à l'encontre des activités intensives en main d'œuvre ; v) renforcer la confiance, et donc l'investissement, en rendant la législation fiscale et son application plus claires et prévisibles ; vi) améliorer la capacité des états et municipalités à offrir des services publics et infrastructure de base. Ce document présente les principales caractéristiques du système fiscal indien, les justifications et possibilités de réforme.

Classification JEL : H20, H24, H25, H26, H71

Mots-clés : Inde, système fiscal, impôt sur le revenu, impôt sur la propriété, impôt sur les héritages, administration fiscale, érosion de la base d'imposition et transfert de bénéfices 


\section{TABLE OF CONTENTS}

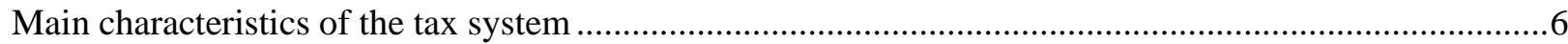

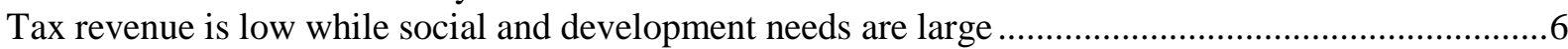

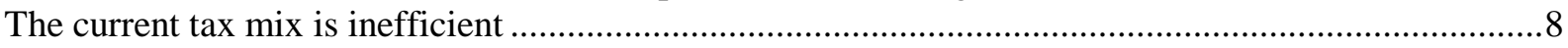

Taxing powers of states and local governments need to increase ......................................................10

The personal income tax could raise more revenue and redistribute more .............................................11

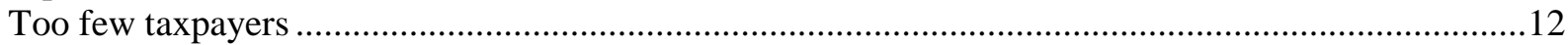

The personal income tax provides little progressivity .........................................................................14

Social security contributions penalise job creation in the formal sector................................................16

Property taxes could help finance better municipal services ...........................................................17

Company taxation: cutting rates and broadening the base to boost firm growth and job creation ............19

A high corporate income tax rate with a narrow tax base ..................................................................

The taxation of SMEs: reducing disincentives to grow and to incorporate.........................................24

International considerations: attracting foreign investors while addressing base erosion and profit

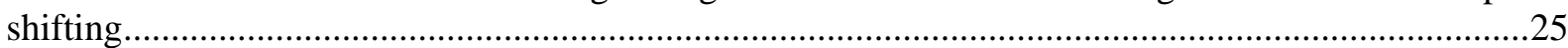

There is scope to improve the effectiveness of the tax administration and increase compliance .............29

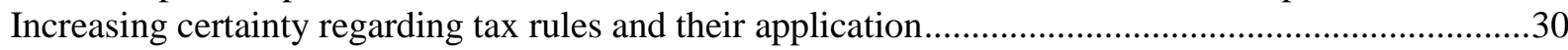

Increasing the overall capacity of the tax administration ......................................................................

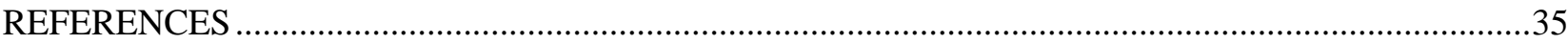

\section{Tables}

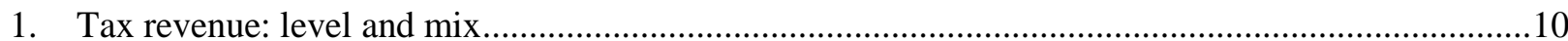

2. Reform options for raising more personal income tax revenue: 4 scenarios ..................................15

3. The average tax wedge decreases along the income ladder in India .............................................17

4. Major incentives granted to companies under the central government income tax ...........................21

5. Tax depreciation rates and true economic depreciation rates for selected assets in India ..................22

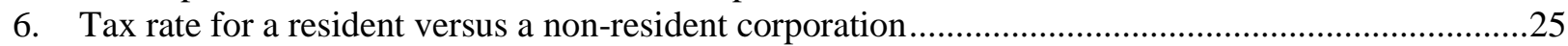

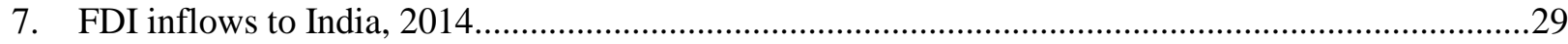

\section{Figures}

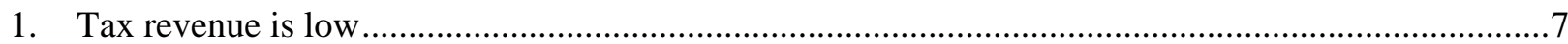

2. The tax mix: indirect taxes and states' own taxes account for a large share ....................................

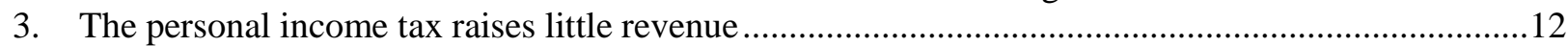

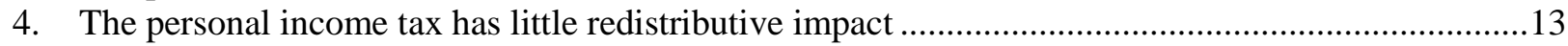

5. Corporate income tax: high statutory rate and many distortions ....................................................20

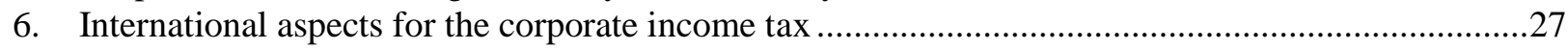

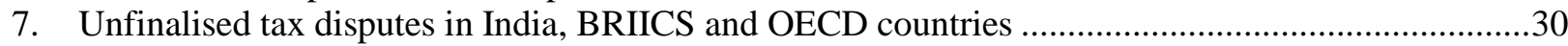

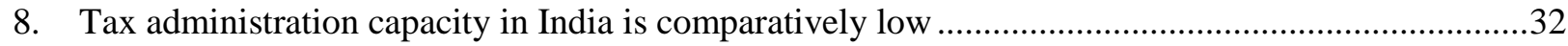

\section{Boxes}

1. The Goods and Service Tax (GST) bill 
2. The allocation of taxing powers across levels of government in India .............................................11

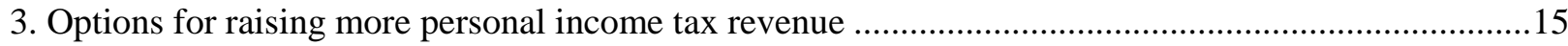

4. The Hindu Undivided Family …….........................................................................................

5. Taxing immovable property - lessons from the literature and from other countries.............................18

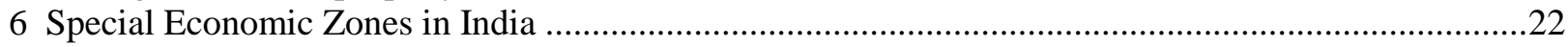

7 Tax rate calculations for resident and non-resident corporations ....................................................25

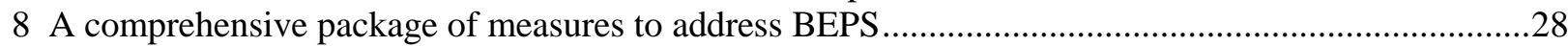

9 Key recommendations of the Tax Administration Review Commission (TARC) ................................33 


\title{
MAKING INCOME AND PROPERTY TAXES MORE GROWTH-FRIENDLY AND REDISTRIBUTIVE IN INDIA
}

\author{
By Isabelle Joumard, Alastair Thomas and Hermes Morgavi ${ }^{1}$
}

\section{Main characteristics of the tax system}

\section{Tax revenue is low while social and development needs are large}

Tax revenue of the central government and states stood at 16.9\% of GDP in fiscal year (FY) 2015/16 - well below most OECD countries and emerging economies (Figure 1.A). In addition, many emerging economies derive revenue from commodities whereas India is a net commodity importer. Since the early 1990s, India's tax-to-GDP ratio has remained broadly constant. This has resulted in a relatively large fiscal deficit and has left little room to fund public investment (Figures 1.B and 1.C).

India needs to raise more tax revenue to finance much needed investment in social and physical infrastructure while bringing the already high debt-to-GDP ratio (68\% in FY 2015/16) to a prudent level (Joumard et al., forthcoming). Spending on core public services is low, leaving a large part of the population un- or under-served. As an illustration, public spending on health amounts to slightly more than $1 \%$ of GDP, far below the level in other emerging economies, while only a very small fraction of the population is covered by a retirement scheme. Less than $40 \%$ of the population has access to sanitation facilities and one fifth is not yet connected to the electricity grid, with large variations across states and between urban and rural areas. In addition to reducing well-being, the lack of infrastructure - in particular electricity and transport - is also a major constraint on growth and on manufacturing in particular (OECD, 2014).

1. Isabelle Joumard is a Senior Economist at the OECD Economics Department; Alastair Thomas is a Senior Economist at the OECD Centre for Tax Policy and Administration; and Hermes Morgavi is a Statistician at the OECD Economics Department. They thank Indian officials, members of the Economic and Development Review Committee, Alvaro Pereira, Robert Ford, Piritta Sorsa, Peter Hoeller, Asa Johannson (OECD Economics Department), David Bradbury and Bert Brys (OECD Centre for Tax Policy and Administration) for their valuable comments. Special thanks are due to Anthony Bolton (also from the OECD Economics Department) for secretarial assistance. 
Figure 1 Tax revenue is low

\section{A. India's tax-to-GDP ratio is low}

2015 or latest year available

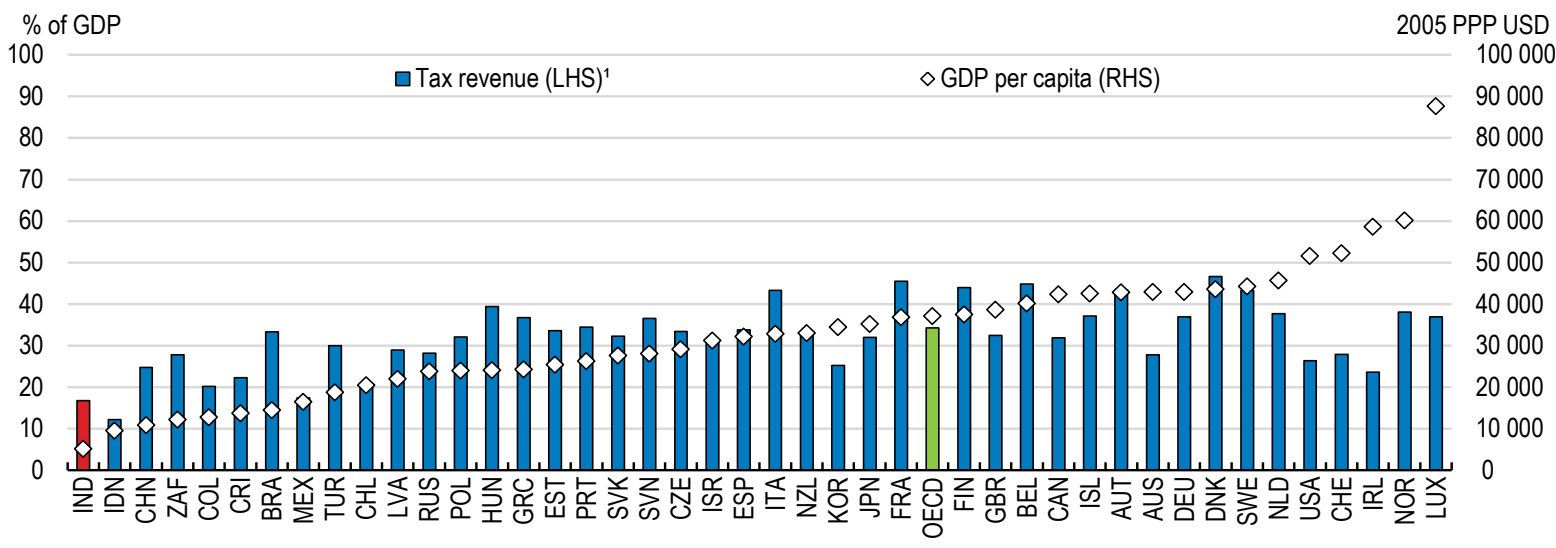

B. Tax and spending to GDP ratio in India

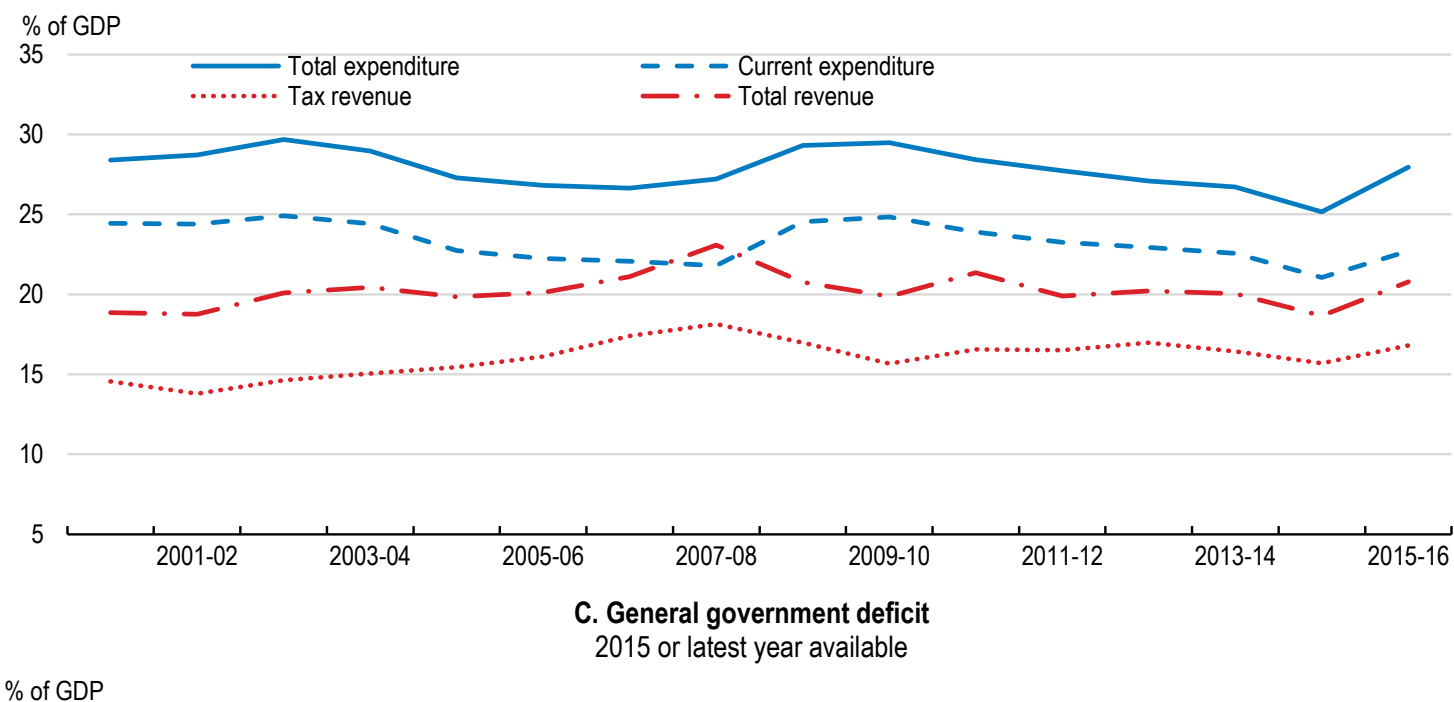

15

10

5

0

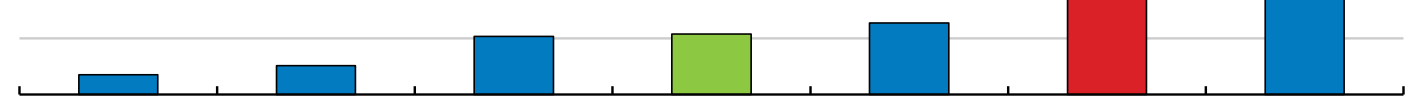

$\begin{array}{llllll}\text { Mexico } & \text { China } & \text { Indonesia } & \text { OECD } & \text { Brazil }\end{array}$

1. Tax revenue includes social security contributions.

2. Data for India are revised estimates by the Reserve Bank of India for the fiscal year 2015-16.

Source: OECD Economic Outlook 100 database; OECD Revenue Statistics database; World Bank; Reserve Bank of India; Central Statistics Organisation. 


\section{The current tax mix is inefficient}

Taxes on goods and services account for the bulk of total tax revenue (Figure 2.A). They consist of value-added and sales taxes (levied at both the central government and state levels), customs duties, as well as a vast array of excise and other duties. These taxes are complex to comply with and involve tax cascading - i.e. taxes on inputs cannot be fully deducted from taxes on outputs - weighing on India's competitiveness. The long-awaited Goods and Services Tax (GST) reform will replace most of these taxes and redress the related inefficiencies (Box 1), although effective implementation will be key to its success. The potential to raise additional revenue from taxes on goods and services is however limited since: i) at $10 \%$ of GDP, they already account for more than $60 \%$ of total tax revenue; ii) the GST reform has been designed to be revenue-neutral, at least in the short term; and iii) consumption taxes tend to affect the poor more.

Figure 2 The tax mix: indirect taxes and states' own taxes account for a large share

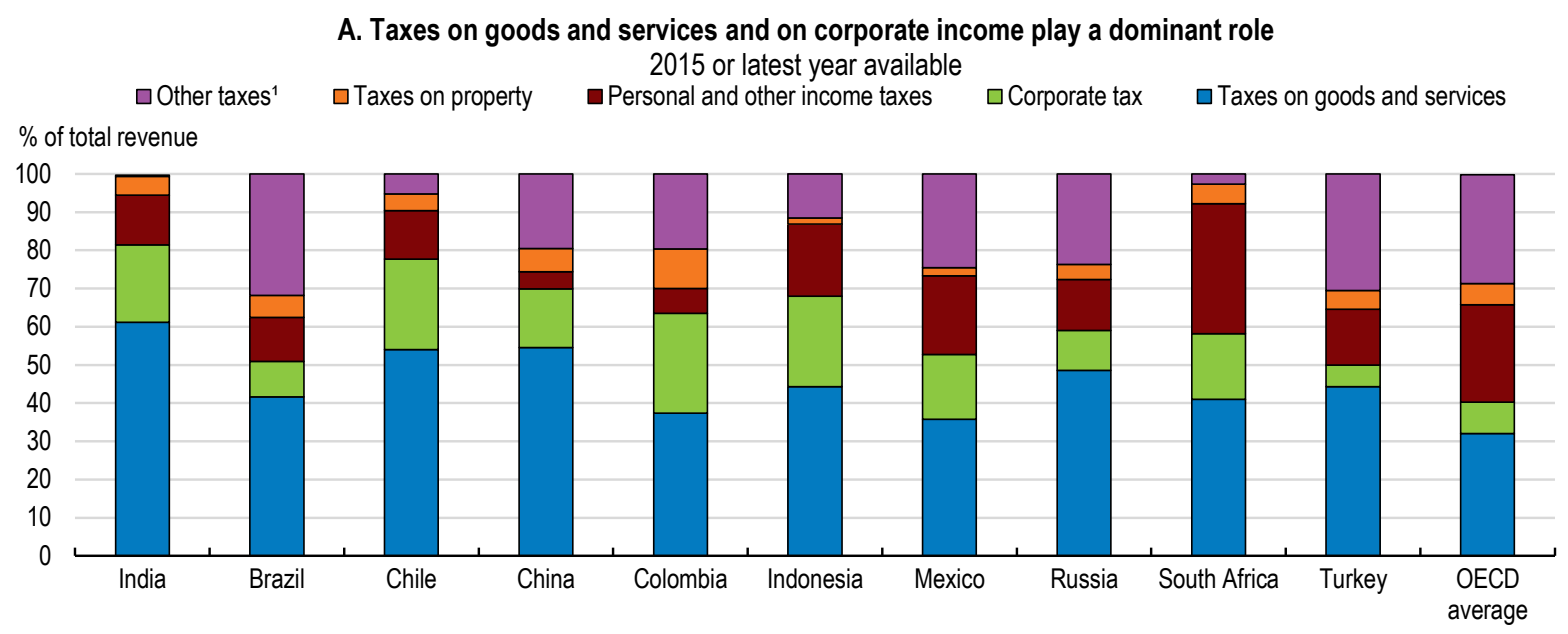

B. The central government share in total tax revenue is relatively low, 2015

口Federal or central government $\quad \square$ Subnational government own taxes $\quad$ घStates' share in central taxes $\quad \square$ Social security funds

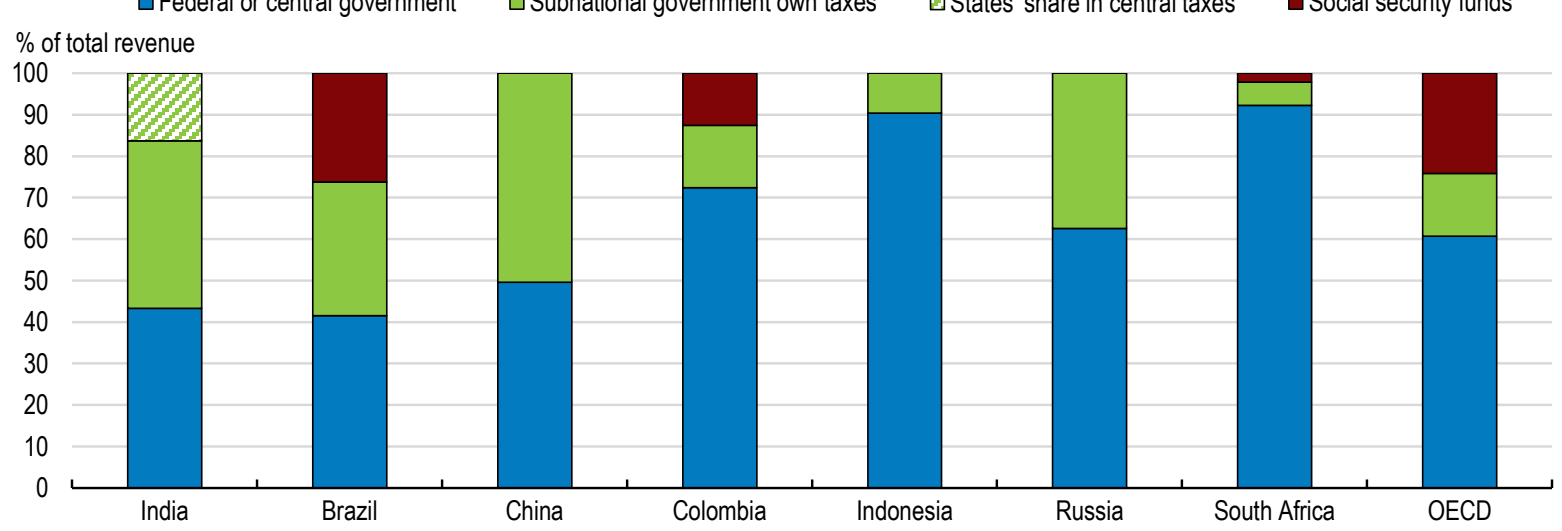

1. Including social security contributions, taxes on payroll and workforce and other taxes.

2. States' share in central taxes has increase in 2016 as, following the recommendation by the 14th Finance Commission, the government has raised states' share of the "divisible tax good" from $32 \%$ to $42 \%$. The implementation of the GST will reduce states' own taxes and increases states' share in central taxes.

Source: OECD Revenue Statistics database; Ministry of Finance of India; and IMF. 


\section{Box 1. The Goods and Service Tax (GST) bill}

\section{Key objectives of the GST}

The GST will replace various taxes on goods and services levied by the central government and states by a single tax on value added. It will thus reduce tax cascading, facilitate a common national market, encourage voluntary tax compliance, reduce tax collection costs, support investment and improve competitiveness. All taxpayer services, such as registration, returns and payments will be available online, which would make compliance easy and transparent.

The GST reform is intended to be revenue neutral although it may affect the allocation of revenue both across states and between states and the central government. However, the central government has committed to compensate states fully for any loss in revenue they suffer in the five years following the implementation of the GST.

\section{Designing the GST}

The GST Council has been constituted, with a two-thirds vote share for the states. It is responsible for recommending tax rates, exemptions, threshold limits and special provisions for certain states and devising the mechanism for resolving disputes.

A four-rate structure has been proposed: $6 \%$ on essential items; two standard rates at $12 \%$ and $18 \%$; and a higher rate of $26 \%$ on luxury goods. A tax over and above $28 \%$ will be imposed on some luxury, sin and demerit goods (including sodas, tobacco and luxury cars). There will be about 100 items exempted (mainly food). Petroleum products, alcohol, electricity and real estate are excluded. Firms with a turnover of less than INR 2 million (about USD 30 000) will be exempted except in the North-eastern states where a lower exemption limit of INR 1 million will apply. The complex rate structure creates the possibility of mis-declaration to benefit from lower rates or exemptions.

Administrative control will be split between the central government and the states. States will assess $90 \%$ of businesses with an annual turnover of INR 15 million or less (about USD 221000 ) while the central government will assess the remaining $10 \%$. States will assess $50 \%$ of larger businesses, with the remaining $50 \%$ assessed by the central government.

\section{Next steps to implement the GST}

The government's objective is to introduce the GST from July 2017 as the existing system of indirect taxation is due to lapse in September 2017. The IT infrastructure is being developed and tax officers will have to be trained. Consultations, workshops and training sessions for the industry, traders, staff and all other stakeholders involved have begun.

The amount of revenue raised through the corporate income tax (CIT) is high compared with other BRIICS and OECD countries (Table 1). The government announced a welcome reform in the 2015 Budget which will reduce the CIT rate from $30 \%$ to $25 \%$ and broaden its base. Some steps in this direction have already been taken (see below). Providing more certainty for potential investors regarding tax rules, their interpretation and application, will also be crucial to creating an attractive environment for foreign investment.

Reforming the personal income tax and property taxes should be given priority to meet financing needs and increase the redistributive impact of taxes. As in many emerging economies, the low level of income of a large share of the population and rampant informality are challenging. However, income and property taxes in India are lower than in several other emerging economies. The number of taxpayers is extremely low while capital and agricultural income is largely untaxed. Experience in some countries with large informal sectors, in particular China, Colombia and South Africa, suggests that there are options to increase the coverage of these taxes. 
Table 1 Tax revenue: level and mix

as a \% of GDP

\begin{tabular}{lrrrrrrr}
\hline & Brazil & China & India & Indonesia & Russia & $\begin{array}{c}\text { South } \\
\text { Africa }\end{array}$ & OECD \\
& 2014 & 2013 & 2014 & 2014 & 2014 & 2014 & 2014 \\
\hline Taxes on income & 6.9 & 4.9 & 5.6 & 5.2 & 6.7 & 14.3 & 11.5 \\
$\quad$ Individuals & 2.5 & 1.1 & 2.2 & 2.3 & 3.4 & 8.9 & 8.4 \\
$\quad$ Corporations & 3.1 & 3.8 & 3.4 & 2.9 & 2.9 & 4.8 & 2.8 \\
$\quad$ Unallocated & 1.3 & 0.0 & 0.0 & 0.0 & 0.4 & 0.5 & 0.3 \\
Social security contributions & 9.6 & 4.6 & 0.0 & 0.0 & 6.7 & 0.8 & 9.5 \\
\hline Taxes on property & 1.9 & 1.5 & 0.8 & 0.2 & 1.1 & 1.4 & 1.9 \\
\hline Taxes on goods and services & 13.9 & 13.5 & 10.3 & 5.4 & 13.7 & 11.4 & 11.0 \\
\hline Other taxes & 1.0 & 0.2 & 0.1 & 1.4 & 0.0 & 0.0 & 0.2 \\
Total tax revenue & $\mathbf{3 3 . 4}$ & $\mathbf{2 4 . 8}$ & $\mathbf{1 6 . 8}$ & $\mathbf{1 2 . 2}$ & $\mathbf{2 8 . 2}$ & $\mathbf{2 7 . 8}$ & $\mathbf{3 4 . 2}$ \\
\hline
\end{tabular}

Source: OECD Revenue Statistics database; IMF; and India's Ministry of Finance.

\section{Taxing powers of states and local governments need to increase}

Providing sub-national governments with greater tax autonomy would allow them to better meet local citizens' needs. It would also help better match their large autonomy in spending, increase accountability, provide an incentive to grow their tax base and support the move towards competitive and co-operative federalism. The allocation of taxing powers between the central government and the states is defined in the Constitution (Box 2). States' own taxes currently account for a relatively large share of total taxes (Figure 2.B). However, the implementation of the GST will reduce states' autonomy as most taxes on goods will be subsumed into the new GST. Municipalities' revenue raising powers are not clearly established.

There is room to raise sub-national taxes. Property taxes, which are typically sub-national government taxes in most decentralised countries, are extremely low in India. Some states levy a professional tax on individuals, which applies to business owners, individuals working in private companies and merchants. Rates and thresholds vary across states but any amount paid is deducted from the central government's personal income tax. Overall revenue is limited, however, as the professional tax has been capped by central government at INR 2500 per year, unchanged since 1988. States are also entitled to levy a tax on agricultural income and land revenue but seldom exercise this right. Overall, income taxes (professional tax and tax on agricultural income) account for less than $2 \%$ of states' own tax revenue, suggesting that there is scope to raise states' income taxes. One avenue is to raise the cap on the professional tax while eliminating deductibility from the central government income tax. This would both increase states' tax autonomy and improve states' accountability since any increase in state taxes would result in an increase in the taxpayer's total (state plus federal) tax liability. 


\section{Box 2. The allocation of taxing powers across levels of government in India}

The Constitution currently allows the central government to levy taxes on the production of goods and the provision of services but not on the sale of goods at later stages, with the exception of inter-state sales - the implementation of the GST will change this. Only the central government is allowed to impose tariffs on international trade, including duties designed to ensure that imports are subject to the same central VAT as domestically produced goods. The central government also taxes personal income (non-agricultural), corporate income and services. It implements an excise duty on tobacco and non-alcoholic products.

\section{State taxes:}

- Tax on the sale of goods within their boundaries. The main tax on goods is the VAT introduced in 2005 to replace the sales taxes (services are not taxed at the state level).

- Tax on agricultural income and land revenue.

- Luxury tax, entertainment tax, excise duty on alcohol, tax on motor vehicles, tax on passengers and goods transported by motor vehicles, and electricity duty.

- Professional tax is imposed on anyone earning a salary or from an income from a profession such as lawyer, doctor or accountant. It is levied by state governments or municipalities. The Constitution, however, fixes a ceiling of INR 2500 per taxpayer per year (unchanged since 1988). The professional tax varies significantly across states. Some states have no professional tax (including Rajasthan) but most impose a progressive levy with a maximum amount of about INR 200 per month. Delhi implements relatively high and progressive rates but with a large tax allowance. At present, 21 states levy a professional tax. In states such as Kerala and Tamil Nadu, municipalities also levy this tax.

\section{Municipalities}

The Constitution authorises states to devolve the power to levy taxes, duties, fees and tolls, to local authorities. It does not embody a separate list of taxes for local bodies, however. The main local taxes are as follows:

- The recurrent tax on immovable property is mainly levied by local authorities, if states have devolved them some powers to set the base and rates and to enforce it.

- Some states, including Maharashtra, allow urban local bodies to levy a tax (Octroi) on the entry of goods into a local area for consumption, use or sale.

- Taxes on luxuries (entertainment, betting and gambling).

\section{The personal income tax could raise more revenue and redistribute more}

Revenue from the personal income tax is low by international standards (Figure 3) and the redistributive impact is limited. This reflects: i) a very large zero rate tax bracket that effectively excludes many taxpayers; ii) low rates which kick in at very high income levels; iii) generous specific tax concessions, which benefit the rich more than the poor; iv) low capital income taxation at the individual level; and v) pervasive tax avoidance and evasion. 
Figure 3. The personal income tax raises little revenue

Revenue from the personal income tax 2015 or latest year

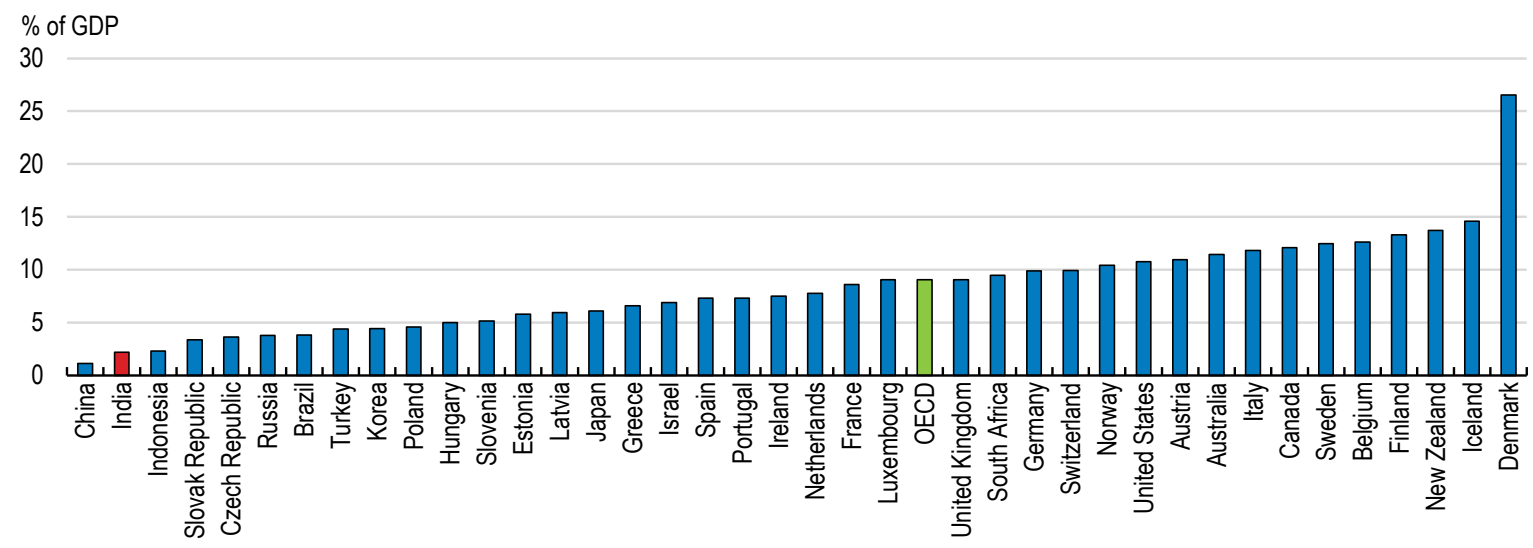

Note: Social security contributions are not included.

Source: OECD Revenue Statistics database; Chinese Ministry of Finance; Indian Ministry of Finance; Rosstat; and South African Ministry of Finance.

\section{Too few taxpayers}

Only $5.6 \%$ of the population pay personal income tax - a very low share by international standards and a limit to the effective functioning of a democracy according to the government (Government of India, 2016a). As in many emerging economies, the large degree of labour market informality is a key challenge for personal income taxation. The bulk of those paying income taxes are salaried employees whose companies are responsible for making their tax payments. However, the zero-rate tax bracket is very wide and its value to the taxpayer increases with the taxpayer's marginal income tax rate, meaning it disproportionately benefits richer workers. An individual did not pay any income tax until income was around two times above per capita GDP and two and a half times the average wage in the organised industrial sector in FY 2015/16 - a threshold much higher than in other emerging economies (Figure 4.A). Thus, most employees are not liable to pay personal income tax, even those working in the formal/organised sector. A recent study estimated that if the exemption threshold had remained unchanged from its FY 2004/05 level, the number of people filing a return would be four times higher (NIPFP, 2015).

Self- and family-entrepreneurs, professionals (e.g. doctors and lawyers) and small traders who largely operate in cash can hide much of their income. Under-reporting is also believed to be common among the rich, with a negative impact on tax morale and compliance by lower income taxpayers. Only 2904 taxpayers reported annual income above INR 50 million (about USD 0.7 million) in FY 2012/13, which seems low compared with other indicators of income and wealth - 13200 Indians had net wealth above USD 10 million according to Credit Suisse (2015).

Agricultural income is untaxed, while agriculture accounts for about 50\% of total employment and $18 \%$ of India's value added. Most farmers are small and earn very little income. However, some are wealthy and could pay income tax. Not taxing agricultural income generates horizontal inequity and creates an incentive to keep resources in a sector with low productivity or to declare non-agricultural income as agricultural income. The political economy of removing this exemption would likely be challenging. In addition, the Constitution currently provides the right to tax agriculture solely to the states, and not to the central government. A communication campaign would, however, help, emphasising that most agricultural workers would not be affected as they would remain in the (generous) zero rate tax bracket. 
Figure 4 The personal income tax has little redistributive impact

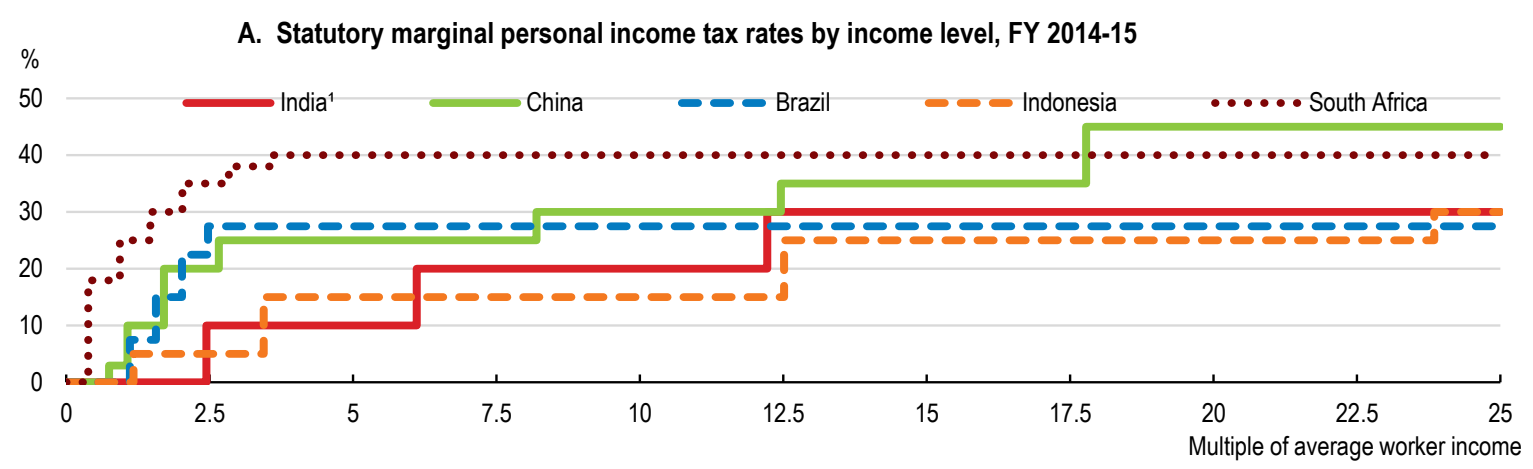

\section{B. Structural progressivity²}

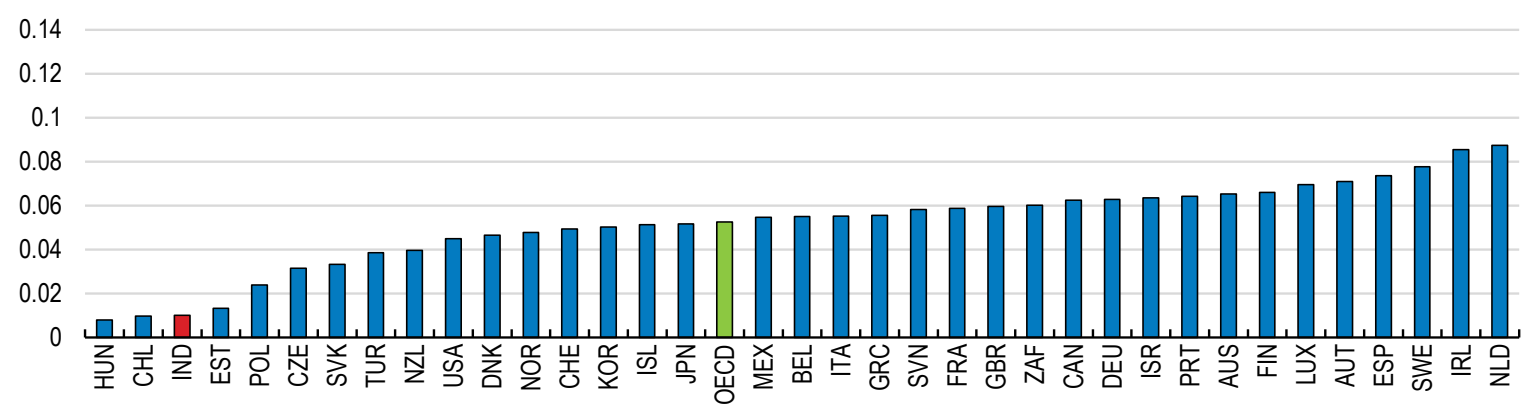

C. Top statutory tax rate

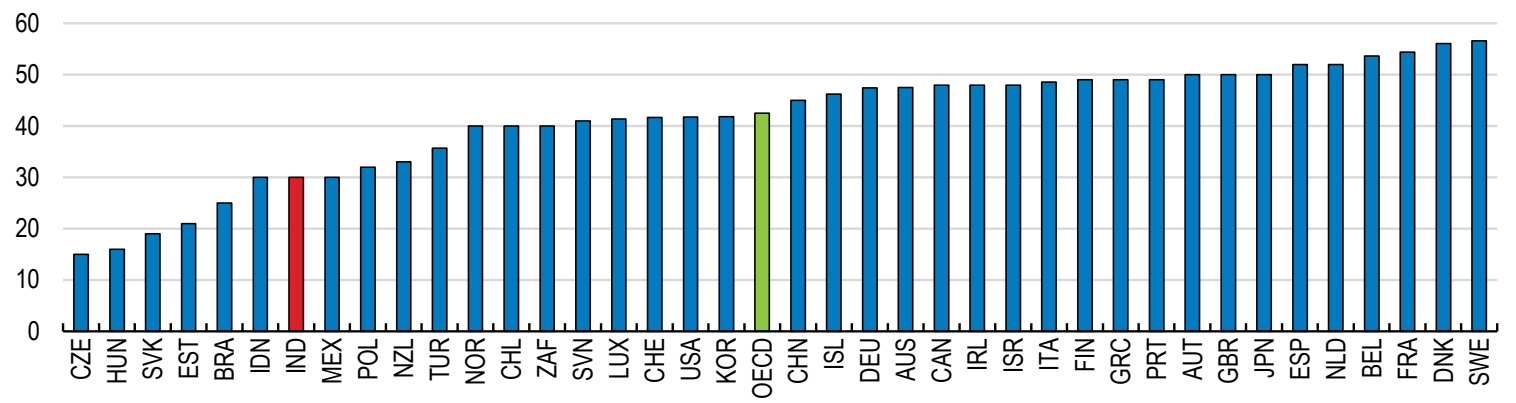

D. Basic exemption and income level from which the top statutory rate applies

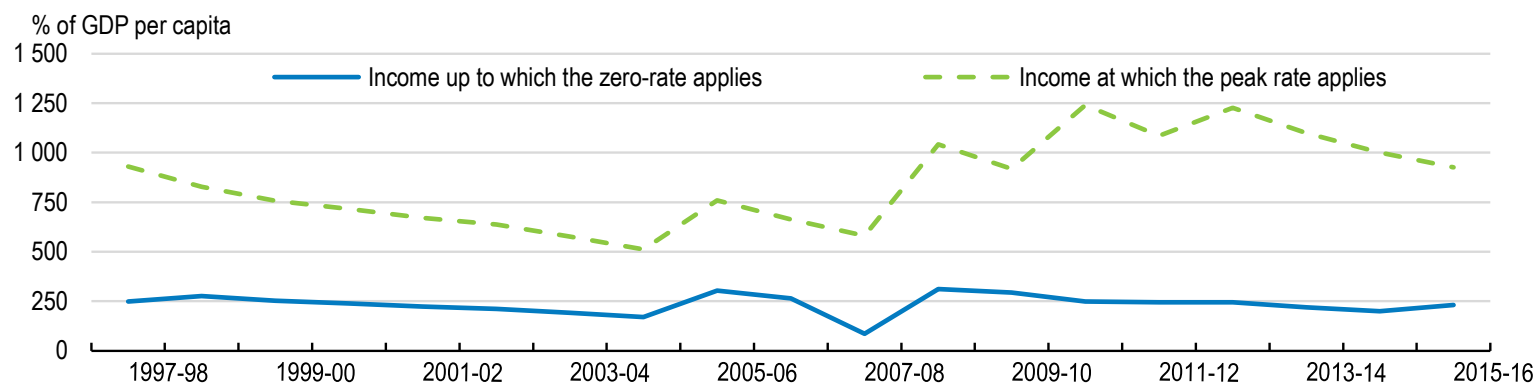

1. The average worker income is for the organised manufacturing sector as reported in the Annual Survey of Industries.

2. The structural progressivity indicator for personal income tax measures the percentage point increase of the average tax rate per percentage point increase of the average wage over the $50 \%-500 \%$ of the average wage income interval. That is the increase in the average tax rate inducted by an increase of the average wage by one percentage point. As such, it does not take account of India's top personal income tax rate which kicks in at around $1200 \%$ of the average wage. Calculations for India and South Africa are for 2015. Data for OECD countries are for 2012. The OECD average is unweighted.

Source: Ministry of Finance; Central Statistics Office; Annual Survey of Industries; OECD calculations; and OECD Taxing Wages 2015. 
There is a clear need to increase the number of taxpayers, as recognised by the government. The objective announced in June 2016 is to double the number of taxpayers to 100 million. Recent efforts to reduce the size of the black economy (in particular the replacement of large notes in November 2016 and the cut in threshold limits for reporting financial transactions under the income tax rules) will be instrumental in improving tax compliance. Experience in other emerging economies reveals that adjusting tax parameters would also help reach the government objective. South Africa has simplified the tax structure and broadened the tax base; the number of registered taxpayers increased from $11 \%$ to $30 \%$ of the population between 2010 and 2014 (OECD, 2015a). China also succeeded in increasing the number of taxpayers from less than $0.1 \%$ in 1986 to about $15-20 \%$ in the 2000 s by under-indexing the basic exemption (Piketty and Qian, 2009).

\section{The personal income tax provides little progressivity}

The personal income tax is not very progressive. At $30 \%$, the top rate is relatively low internationally (Figure 4.C) although the top effective marginal rate increases with the 12\% surcharge on the amount of tax payable on total income exceeding INR 10 million (USD 0.2 million). This surcharge was introduced in FY 2015/16 when the wealth tax was abolished. An additional 2\% education "cess" (i.e. earmarked tax) is levied on the income tax liability. However, the income level at which the top rate kicks in has been increased over time and now stands at about 10 times GDP per capita (Figure 4.D). The average income of those who pay the top (30\%) marginal rate corresponds to the $99.5^{\text {th }}$ percentile (Government of India, 2016a). The overall OECD structural progressivity index, calculated as the ratio of the change in the average PIT rate relative to a given increase in income, indicates that the statutory system provides much less progressivity than most OECD and other emerging economies - the contrast with South Africa is particularly strong (Figure 4.B).

A host of specific tax expenditures further reduces the tax liabilities of the well-off. Repayment of mortgage principal and interest, as well as interest on loans for higher education, are deductible from taxable income without limit. Other tax allowances are capped, including: pension contributions or life insurance payments up to INR 150000 per year (about USD 2 250), medical insurance premiums up to INR 15000 and medical expenses not covered by insurance up to INR 40000 . A government estimate suggests that overall tax expenditures that reduce personal income tax payments amounted to INR 535 billion in FY 2014/15, i.e. $20 \%$ of actual personal income tax revenue. Streamlining tax expenditures would allow more revenue to be raised, reduce distortions in resource allocation, and make the tax system fairer and simpler. For those tax expenditures that cannot be eliminated, replacing tax allowances by nominal tax credits, as has occurred in South Africa for contributions to medical funds, would help to increase the actual progressivity of the personal income tax. Another approach, implemented in Colombia in 2012, is to cap tax expenditures for rich households to ensure that they pay some minimum income tax.

The taxation of capital income at the personal level is low, if not nil, and flat in most cases, with the implicit tax subsidy benefitting the rich most. Tax rates vary across asset classes and long-term capital gains are given a preferential treatment, although long-term is defined in different ways for different asset classes. Capital gains are taxed upon realisation but if the underlying asset is held for at least three years (one year for listed shares), gains may be exempt if reinvested in certain securities or sectors. Bonds issued by designated public enterprises are tax-free. Pension savings (Employees', Voluntary and Personal Provident Funds) are exempted from taxes at all three stages, i.e. at the time of initial saving, during the period when the funds are invested, and when the investment is liquidated and a pension is paid out. While the 2016/17 Budget envisaged taxing some (60\%) of the interest earned, fierce opposition from trade unions led the government to maintain the generous tax treatment of pension savings. 
Distributed dividends are tax exempt in the hands of personal shareholders. However, a dividend distribution tax of $15 \%$ is withheld by corporations on distribution, with no relief granted for corporate income tax already paid. ${ }^{2}$ When taking account of both the tax paid at the corporate level and the dividend distribution tax, the effective statutory tax rate on dividends is relatively high. Such a system has pros and cons. A dividend tax withheld at the corporate level is easier to administer - there are less corporations distributing dividends than personal shareholders receiving dividends - and more difficult to evade. However, such an approach does not allow dividends to be taxed at progressive income tax rates.

Bringing India's income tax thresholds more into line with other emerging economies and abolishing tax expenditures would increase personal income tax revenue significantly. Simulations based on conservative assumptions suggest that revenue would increase by about 50\% (Box 3). The revenue impact of lowering the threshold from which the top personal income tax rate applies and of scrapping income tax concessions is particularly high.

\section{Box 3. Options for raising more personal income tax revenue}

To gauge the potential revenue impact of bringing the Indian personal income tax schedule more in line with other emerging economies, simulations have been run, using the income tax return statistics recently released by the Ministry of Finance. Information on the number of individual taxpayers is available by income classes. Based on statutory rates and thresholds (including for the basic allowance), one can estimate how much tax should be paid by the average taxpayer in each income class. Simulations are carried out by changing the thresholds above which statutory rates apply.

Assuming that changes in income thresholds do not alter individuals' behaviour, the full set of underlying reforms would increase personal income tax revenue by about $50 \%$ (Table 2). Although this assumption may be too optimistic, the impact of implicit income tax reforms is likely vastly underestimated since:

1. The simulation does not include the taxation of agricultural income as any other income nor the potential reduction in income under-declaration since the lack of data makes the calibration difficult.

2. The revenue impact of lowering the threshold at which the top income tax rate kicks in is difficult to assess in the absence of additional information on the distribution of income. If one uses a Pareto interpolation of the income distribution for top incomes, as suggested by Piketty (2001), instead of the "average taxpayer" for this class, the estimated impact would be more than double the amount shown here.

3. Dismantling the Hindu Undivided Family (HUF) system (see below) would yield additional revenue which is, however, difficult to assess in the absence of data on who possesses HUFs' assets and income.

4. The simulation adds up the impact of reforms while the implicit value of abolishing concessions will likely be higher if the income tax rate schedule is reformed.

Table 2. Reform options for raising more personal income tax revenue: 4 scenarios

\begin{tabular}{|c|c|}
\hline $\begin{array}{l}\text { compa } \\
\text { (for }\end{array}$ & $\begin{array}{l}\text { e in revenue } \\
\text { actual PIT revenue } \\
\text { ividuals and HUFs) }\end{array}$ \\
\hline \multicolumn{2}{|l|}{ Personal income tax on individuals } \\
\hline 1. Reduce the income threshold at which the PIT top rate kicks in to $500 \%$ of the average wage ${ }^{a, b}$ & $18.2 \%$ \\
\hline 2. Reduce the income threshold at which the zero tax band applies to $100 \%$ of the average wage ${ }^{\text {a, b }}$ & $3.3 \%$ \\
\hline 3. Reduce the income threshold at which the $20 \%$ rate kicks in to $300 \%$ of the average wage ${ }^{b}$ & $7.8 \%$ \\
\hline \multicolumn{2}{|l|}{ Income tax concessions } \\
\hline 4. Scrap all personal income tax concessions & $19.6 \%$ \\
\hline Implementing all measures & $48.9 \%$ \\
\hline \multicolumn{2}{|c|}{$\begin{array}{l}\text { a. Under this scenario, the } 20 \% \text { tax rate does not apply since it kicks in at } 5.6 \text { times the average worker income under the existing tax schedule, } \\
\text { i.e. above the proposed } 500 \% \text { threshold for the top rate. }\end{array}$} \\
\hline \multicolumn{2}{|c|}{ Source: OECD calculations based on data from the Income Tax Department - Income Tax Return Statistics Assessment Year 2014-15. } \\
\hline
\end{tabular}


The Hindu Undivided Family (HUF) system (Box 4) offers those with substantial property income an avenue to reduce their tax liabilities. An individual can file two income tax returns, one in his/her individual capacity and a second in the name of his HUF. Overall, 940000 HUFs filed an income tax return in FY 2014/15. When an individual files two income tax returns (one for his own income, the other one for the HUF), the level of tax-free income doubles to INR 500000 (USD 7800 ). Additional tax expenditures and deductions can be claimed. Overall, the family's income tax liability declines significantly. If a parent bequeaths property to an adult child as chief (Karta) of a new HUF, the child can treat this property as separate from his own property so that the income generated from the property in the new HUF will be taxed at the new HUF entity rather than to the parent or the child. Overall, the HUF results in lower tax revenues, reduces tax liabilities of the most well-off, creates horizontal inequity across individuals with different family status, and complicates the assessment and collection of income tax (Sanyal, 1995). It also leaves gifts and inheritances basically untaxed.

\section{Box 4. The Hindu Undivided Family}

The Hindu Undivided Family (HUF) is a separate legal entity under the Income tax Act. The HUF is eligible for the basic (very generous) tax exemption as well as the specific exemptions (e.g. for medical expenses) and rebates (e.g. on capital gains), just like an individual.

Any individual who is born Hindu, Sikh, Jain or Buddhist, can form a HUF, provided he is married. The HUF consists of an ancestor (the karta) and all that common ancestor's lineal descendants together with their spouses and unmarried children. Traditionally, the karta is the oldest male family member. When the karta dies, his eldest son becomes the next karta, All the male members (sons, grandsons and great-grandsons of the karta) plus unmarried daughters (only since 2005) are called coparceners, but not granddaughters and great-granddaughters. A coparcener has the right to demand that the family property gets divided, so that they can receive their share in the property, or in whatever assets the HUF holds.

Joint family (both immovable and movable) property which funds the HUF includes: i) ancestral property (i.e. a property received by a Hindu male from his father, paternal grandfather of paternal great grandfather); ii) property that is acquired with HUF assets; iii) property from a partition of a larger HUF; and iv) separate property and gifts that are contributed by a member (under certain limits and conditions). A HUF can also build its capital by borrowing from non-members and the income so earned will only be HUF income. All income arising out of a HUF's property is income of the HUF and will be assessed as its income. A HUF cannot earn labour income, however, as wages are considered a result of personal skills and services.

The decision of some states, including Kerala, not to recognise HUFs should be considered in other states or at the central government level. It would not only allow a fairer taxation of capital income but enable the introduction of inheritance and gift taxes which can reduce income inequality while promoting economic growth. Greater reliance on inheritance and gift taxes would also promote equal opportunity and inter-generational mobility (OECD, 2012; Joumard et al., 2012; Piketty and Saez, 2013; OECD, 2015f).

\section{Social security contributions penalise job creation in the formal sector}

Social security contributions create incentives for firms to stay small or rely on temporary workers (so-called contract workers). Establishments with less than 20 employees do not have to contribute. Employees working in establishments with 20 persons or more have to contribute $12 \%$ of their gross salary to a pension system (the Employee Provident Fund). However, contributing becomes voluntary for those earning more than INR 15000 per month (i.e. about USD 220). Employees also have to contribute 1.75\% of their gross salary for health insurance - to the Employees State Insurance Corporation - but with a cap at a gross salary of INR 15000 per month. In addition, employers have to contribute to the pension and health insurance, with similar caps. Such an approach increases the cost of unqualified labour, thus weighing on job creation in the organised sector and creating incentives for enterprises to rely on informal labour (e.g. contract labour), to stay small, or to evade tax. In practice, the share of employment in firms with more than 20 employees is extremely small by international standards (OECD, 2014a). 
Social security contribution caps also result in regressive taxation: the marginal tax wedge for an employee earning $67 \%$ of the average earning (in a company with more than 20 employees) is higher than for one earning the average wage (Table 3). It is also higher than in Indonesia and South Africa.

Table 3. The average tax wedge decreases along the income ladder in India

Income tax plus employee and employer contributions less cash benefits (\% of labour costs, 2013)

\begin{tabular}{|c|c|c|c|c|c|c|c|c|}
\hline \multirow[b]{2}{*}{ Wage level (\% of AW): } & \multicolumn{7}{|c|}{ single } & \multirow{2}{*}{$\begin{array}{c}\text { married } \\
\text { no ch } \\
100-33 \\
-8 \\
\end{array}$} \\
\hline & $\begin{array}{l}67 \\
-1 \\
\end{array}$ & $\begin{array}{r}100 \\
-2 \\
\end{array}$ & $\begin{array}{r}167 \\
-3 \\
\end{array}$ & $\begin{array}{l}67 \\
-4 \\
\end{array}$ & $\begin{array}{r}100-0 \\
-5 \\
\end{array}$ & $\begin{array}{c}100-33^{1} \\
-6 \\
\end{array}$ & $\begin{array}{c}100-67^{1} \\
-7 \\
\end{array}$ & \\
\hline Brazil & 33.5 & 33.5 & 36.3 & 33.5 & 33.5 & 31.4 & 33.5 & 33.3 \\
\hline China & 34.1 & 33.7 & 35.3 & 34.1 & 33.7 & 35.9 & 33.9 & 35.9 \\
\hline India unorganised sector & 0 & 0 & 0 & 0 & 0 & 0 & 0 & 0 \\
\hline India organised sector ${ }^{2}$ & 26.1 & 6.2 & 6.2 & 26.1 & 6.2 & 11.6 & 14.7 & 11.6 \\
\hline Indonesia & 8.2 & 8.2 & 9.4 & 8.2 & 10.7 & 8.2 & 8.2 & 8.2 \\
\hline South Africa & 10.6 & 14.3 & 19.5 & 10.6 & 14.3 & 11.5 & 12.8 & 11.5 \\
\hline OECD average & 32.3 & 35.9 & 40.3 & 17.7 & 26.6 & 28.3 & 31.2 & 32.9 \\
\hline
\end{tabular}

Note $:$ ch $=$ children

1. Two-earner family.

2. Results apply to employees working in a firm with more than 20 employees. Calculations have been made with the previous INR 6500 threshold for mandatory social security contributions, later raised to INR 15000.

Source: OECD Taxing wages, 2015, Special feature: "Modelling the Tax Burden on Labour Income in Brazil, China, India, Indonesia and South Africa".

To eliminate the adverse impact of social security contributions on quality job creation while offering social benefits to low-income earners, the government should consider two options. The first option would consist of making social security contributions mandatory for all workers, i.e. even for those earning more than the current cap (INR 15000 per month) and for companies with less than 20 employees. Such an approach would reduce the bias against low-qualified jobs. It runs, however, the risk of increasing the use of informal labour and fostering the substitution of capital for labour. The second option would consist of eliminating wage-based social security contributions and financing social benefits through higher general government revenue - this paper argues that there is scope to raise more revenue from the personal income tax and property taxes. Given the existing fiscal constraints, however, an expansion of social benefits could only be gradual, with decisions on the level and coverage of social benefits taking into account existing fiscal constraints, the large number of the poor, as well as the other social programmes targeted at the poor.

\section{Property taxes could help finance better municipal services}

There is scope to raise more revenue from property taxes in India. The wealth tax $(1.1 \%$ of central government's total tax revenue in FY 2013/14) was abolished in 2015, while inheritance taxes are virtually absent despite the extreme concentration of wealth in the hands of a few. A recent survey (Credit Suisse, 2015) suggested that the poorest $30 \%$ households own $0.1 \%$ of total wealth in India while the top $10 \%$ own $62 \%$. This survey also revealed that non-financial assets (i.e. mainly land and agricultural assets) account for the bulk of household wealth $-86 \%$, compared with around 50\% in most other regions of the world. Logically, real estate is the main property tax base in India and both transaction taxes and recurrent taxes on immovable property exist. 
Relatively high stamp duties and registration charges are levied by Indian states on the sale of immovable property. Related state revenues stand at about $0.8 \%$ of GDP despite the fact that market values are often vastly understated. Such transaction taxes discourage people and companies from buying and selling property, impeding the reallocation of property to their most effective use. They also encourage under-reporting, which may inflate the creation of black money. Given current fiscal needs, it should be retained but phased out in the medium run and replaced by the greater use of recurrent taxes on immovable property based on updated property values.

Revenue from recurrent taxes on immovable property stands at about $0.2 \%$ of GDP (Rao, 2013), i.e. well below the level in OECD and other BRIICS countries. Recurrent taxes on immovable property are levied in most states at the local level, a welcome feature given their many advantages as local taxes (Box 5). However, local governments have very limited autonomy to set the bases and rates and to enforce them since they often lack the appropriate workforce. States can decide to abolish them and some have done so (Rao, 2013), creating uncertainty regarding local governments' revenue source. Raising more revenue from recurrent taxes on immovable property would help municipalities to fill the vast municipal infrastructure gaps. To achieve this, India needs to give municipalities more certainty and powers over the bases and rates of recurrent taxes on immovable property.

Raising more revenue from recurrent taxes on immovable property would require up-to-date property valuations and support of local governments' ability to manage the register of these valuations. The out-dated and partial assessment of property values is a key issue in India, as in many other countries. It affects the revenue of recurrent taxes on immovable property and creates horizontal inequities. The coverage rate is low, with wide-ranging exemptions. Assessed values are as low as $8-10 \%$ of their market value. Some municipalities have taken the lead in moving away from the "fair" rental value (i.e. the rent which a similar property with similar features in the same area would fetch), which has historically been used but is difficult to implement. Patna has implemented a presumptive area-based valuation, taking into account the location, usage and type of construction (Rao, 2013). Others (e.g. Bangalore) have introduced a self-assessment system, which was also implemented with success in large Colombian cities (Barranquilla and Bogota), and promoted online payment. The sharing of experience across municipalities would help to implement the best solution given local constraints.

\section{Box 5. Taxing immovable property - lessons from the literature and from other countries}

Reliance on immovable property taxation as a source of revenue for local governments has many merits compared with other taxes (OECD, 2015e; Blöchliger, 2015). First, recurrent taxes on immovable property are closely linked to the benefits taxpayers receive from local public services. By helping fund these services, they reduce local governments' dependence on intergovernmental transfers. Second, it is considered to be one of the least harmful taxes to economic growth. Third, taxes on immovable property are difficult to evade as the base is immobile, allowing local authorities to vary the rates without losing the base. Fourth, they can be designed to have desirable redistributive properties. Because real estate taxes tend to be regressive, some OECD countries have granted relief to low-income households so as to introduce some progressivity (Joumard et al., 2012). Some emerging economies also raise revenue from real estate taxes while preserving progressivity. As an illustration, in Johannesburg (South Africa), residential property's estimated market values are taxed only above a given threshold, and there are rebates for individuals receiving pensions, living below the city's poverty index or temporarily without income (OECD, 2015a). To allow for the uncertainty around the true value of a property, a lump-sum might be deductible from assessed property values.

Although recurrent taxes on immovable property are unloved by voters and taxpayers, several OECD countries adopted and implemented property tax reforms after the financial, economic and fiscal crisis, thereby increasing both revenues and fiscal autonomy of sub-national governments. Recurrent taxes on immovable property today make up around $1 \%$ of GDP in OECD countries. More than $95 \%$ of the revenue accrues to sub-national governments (OECD, 2015b), making it the most important tax revenue for state and local governments in many OECD countries. 


\section{Company taxation: cutting rates and broadening the base to boost firm growth and job creation}

Creating a business-friendly tax environment is key to promoting investment and job creation and to raising India's competitiveness. The latest Enterprise Survey (World Bank, 2014) revealed that among the list of 15 potential business environment obstacles, the level of tax rates comes third after corruption and lack of electricity. The corporate income tax (CIT) is a key revenue source for India - raising $20.6 \%$ of total tax revenue and 4\% of GDP (Figure 5.A), even more than in most emerging economies. As corporate taxes tend to be particularly harmful to growth (Johansson et al., 2008), the priority should not be to raise more CIT revenue but to reduce distortions arising from the CIT.

The 2010 Direct Tax Code (DTC) Bill proposed a simpler tax code, by removing most tax concessions while lowering rates. It aimed at boosting growth by improving the allocation of resources, reducing tax uncertainty and the discretionary power of the tax administration, and lowering the bias against small companies which cannot afford in-house tax experts. Although the Bill lapsed in Parliament, measures have recently been taken to reduce rates while broadening the base and to improve the ease of paying taxes for firms. Some aspects of the tax legislation have also been clarified to provide more certainty for domestic and foreign firms, while measures to curb tax evasion are being implemented. However, more needs to be done.

\section{A high corporate income tax rate with a narrow tax base}

The statutory corporate income tax rate is high compared with other BRIICS and OECD countries (Figure 5.B). For resident companies, the statutory CIT rate stands at $30 \%$, with a lower rate of $25 \%$ for small companies (i.e. turnover less than INR 500 million) and $25 \%$ for new manufacturing companies that do not claim any tax concessions. A $12 \%$ surcharge on the total tax liability applies if taxable income exceeds INR 100 million (about USD 1.6 million) and a 7\% surcharge if taxable income stands between INR 10 million (approx. USD 156000 ) and INR 100 million. In addition, a 2\% education "cess" (earmarked tax) and a 1\% secondary and higher education "cess" are payable on the total tax liability (including surcharge, if applicable). Overall, the statutory rate stands at $34.6 \%$ if taxable income exceeds INR 100 million.

There is a sizeable gap between statutory and effective tax rates, reflecting various special tax rates, exemptions, deductions, rebates, deferrals and credits. A Statement of revenue foregone with estimates on tax expenditure by key categories is presented annually to Parliament since the mid-2000s in the context of budget discussions, contributing to fiscal accountability and transparency. The effective tax rate on companies stood at 23.2\% in FY 2013/14. Tax concessions for companies (in gross terms) are estimated to amount to $0.8 \%$ of GDP. Accelerated depreciation, area-based exemptions and tax relief for infrastructure/network industries account for the bulk of the foregone revenue (Table 4). The tax system has also been used to promote specific industries. As an example, the health care industry benefits from relatively high depreciation for medical equipment, income tax exemptions for five years for rural hospitals, customs duty exemptions for imported equipment that are lifesaving and an income tax exemption for health insurance (Government of India, 2015). To ensure that profitable companies pay at least some tax, India operates a minimum alternate tax (MAT) which reduces the total revenue foregone estimate from $22 \%$ to $14 \%$ of corporate income tax revenue.

Tax concessions introduce economic distortions across firms of different size. Despite the lower surcharge rates imposed on companies with taxable income below INR 10 million, the effective tax rate is higher for small companies (Figure 5.C). This suggests that large companies - that can more easily afford specialist tax advice - are better able to exploit tax concessions. 
Figure 5. Corporate income tax: high statutory rate and many distortions

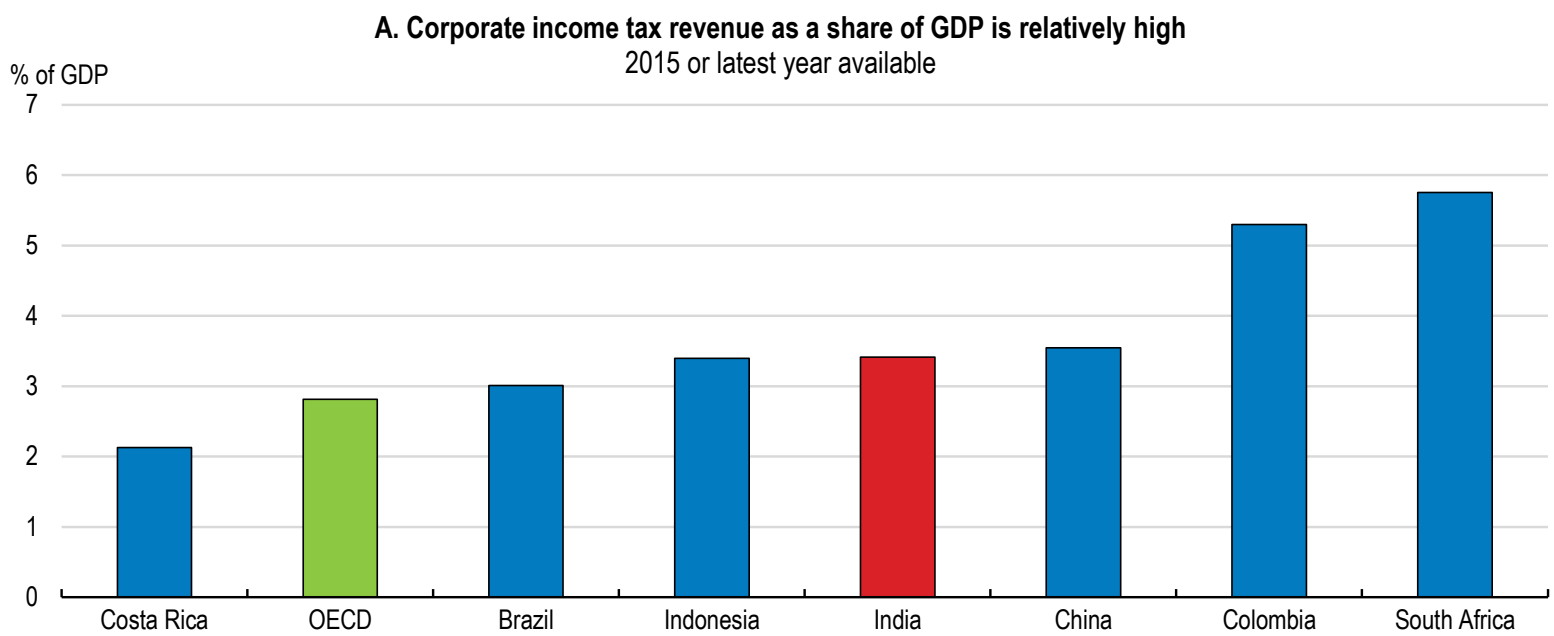

B. The statutory corporate income tax rate is relatively high

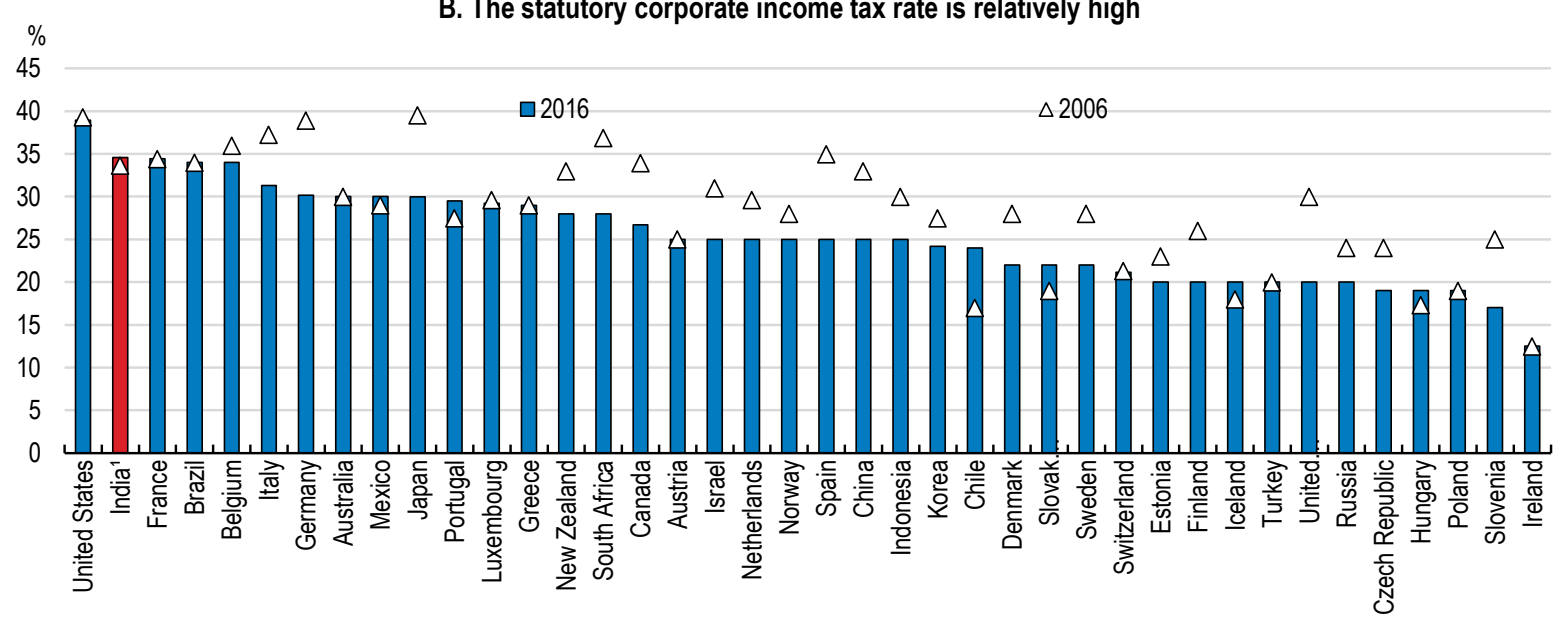

C. The actual effective tax rate is higher for small, labour intensive and private companies

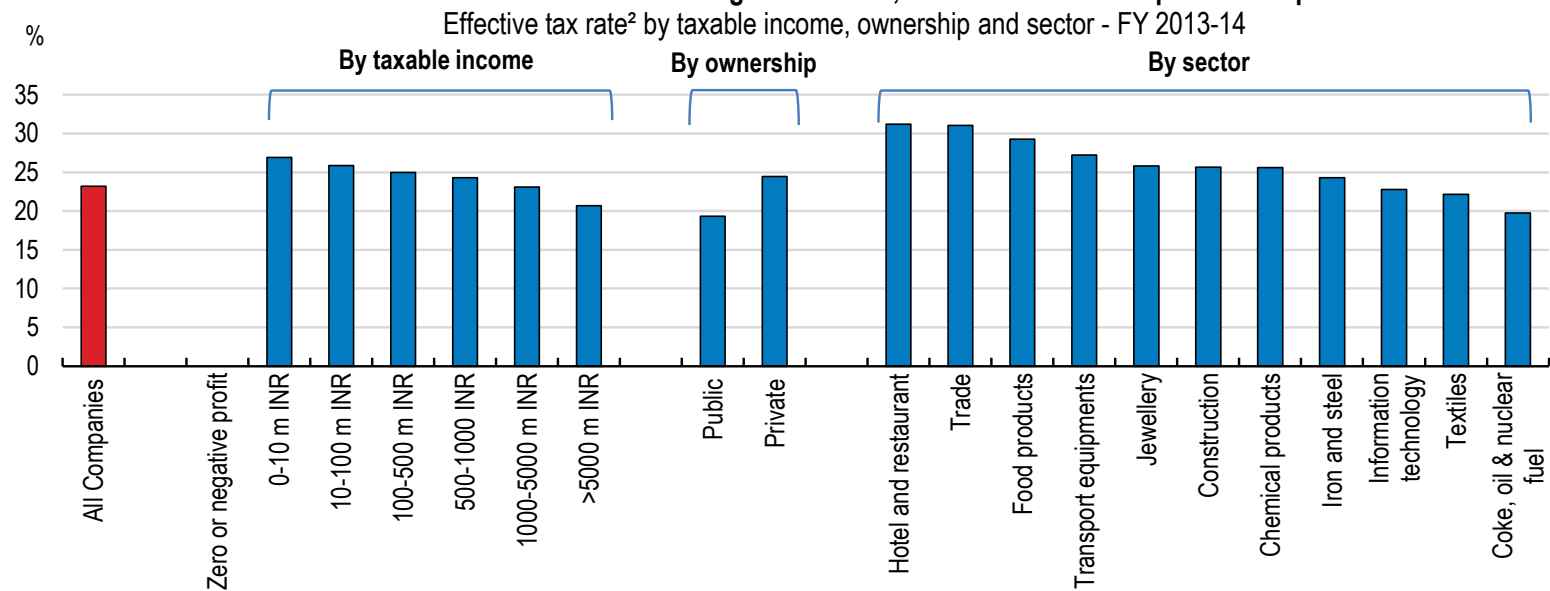

1. The CIT rate stands at $30 \%$. A $12 \%$ surcharge on total tax liabilities applies if taxable income exceeds INR 100 million (7\% if it stands between INR 10 and 100 million), as well as a $3 \%$ cess. Overall, the statutory rate is $34.6 \%$.

2. Tax to profit ratio.

Source: Central Statistics Office of India; OECD Revenue Statistics database; South African Revenue Service; OECD Tax database; Deloitte; Ministry of Finance of India. 
ECO/WKP(2017)21

Table 4 Major incentives granted to companies under the central government income tax (FY 2014-15)

\begin{tabular}{|c|c|c|c|}
\hline & INR billion & $\begin{array}{l}\% \text { of } \mathrm{CIT} \\
\text { revenue }\end{array}$ & $\begin{array}{l}\% \text { of } \\
\text { GDP }\end{array}$ \\
\hline Accelerated depreciation & 370 & $8.2 \%$ & $0.3 \%$ \\
\hline Area-based exemptions & 281 & $6.2 \%$ & $0.2 \%$ \\
\hline Backward areas & 77 & & \\
\hline Special economic zones & 204 & & \\
\hline Infrastructure & 227 & $5.0 \%$ & $0.2 \%$ \\
\hline Telecom & 15 & & \\
\hline Power & 107 & & \\
\hline Oil and natural gas & 67 & & \\
\hline Scientific research & 82 & $1.8 \%$ & $0.1 \%$ \\
\hline Total gross corporate income tax concessions ${ }^{1}$ & 984 & $21.8 \%$ & $0.8 \%$ \\
\hline Recovered through Minimum Alternate $\operatorname{Tax}^{2}$ & 360 & $8.0 \%$ & $0.3 \%$ \\
\hline Net revenue foregone ${ }^{1}$ & 624 & $13.8 \%$ & $0.5 \%$ \\
\hline
\end{tabular}

1. The total gross corporate income tax concessions and net revenue forgone include other smaller concessions not shown above.

2. India operates a minimum alternate tax (MAT) to ensure that profitable companies pay at least some tax. If a company's tax liability is below $18.5 \%$ of its book profits, the book profits are deemed to be taxable income and are subject to the MAT at a rate of $18.5 \%$, plus surcharges.

Source: Statement of revenue impact of tax incentives under the central tax system: financial year 2013-14 and 2014-15; Public Finance Statistics.

The government has committed to a "base broadening - rate reducing" reform whereby the corporate income tax rate will be lowered to $25 \%$ over a five-year period and most tax concessions will be eliminated. The 2016/17 Budget began this process with a rate reduction from 30 to $29 \%$ (plus surcharges) for companies with taxable income below INR 50 million, and to $25 \%$ for new manufacturing companies that do not claim any tax concessions. The FY 2017/18 budget brought down the rate to 25\% for companies with a turnover below INR 500 million. While these steps have lowered the effective rates bias against small companies, these targeted reductions are in conflict with the neutral approach of the overall "base broadening - rate reducing" reform. In order to reduce complexity, it is important that such targeted reductions remain temporary and that the move to a single $25 \%$ corporate tax rate for all companies, together with the elimination of most concessions, is fully implemented at the end of the five year period, if not sooner.

\section{Generous depreciation allowances have created a bias against labour-intensive activities}

Labour-intensive sectors (e.g. hotels and restaurants; retail and wholesale trade) face relatively high effective rates, as they benefit less from the rather generous depreciation allowances. Tax depreciation rates often stand above rates of true economic depreciation for a wide range of assets (Table 5) and tend to be generous by international standards (Oxford University Centre for Business Taxation database). Accelerated depreciation provisions further vary across asset types. As an illustration, spending on commercial vehicles receives a better treatment than $R \& D$ for electronic products and pre-packaged software (Thomas et al., forthcoming). The $40 \%$ cap on depreciation rates (except for R\&D which has a $150 \%$ rate) to be introduced in April 2017 will reduce some biases. Ideally, tax depreciation should be set to approximate true economic depreciation rates. And more should be done to eliminate the biases against labour-intensive activities which run counter to the objective of promoting job creation. 
Table 5 Tax depreciation rates and true economic depreciation rates for selected assets in India

\begin{tabular}{|c|c|c|}
\hline Rates & Tax depreciation & Economic depreciation \\
\hline Non-residential buildings & 0.10 & 0.03 \\
\hline Commercial vehicles & 0.50 & 0.22 \\
\hline Computers (servers and networks) & 0.60 & 0.27 \\
\hline Computers (end-user devices) & 0.60 & 0.73 \\
\hline Plant and machinery (general) & 0.15 & 0.11 \\
\hline Electrical equipment & 0.80 & 0.17 \\
\hline Plant and machinery (pharmaceuticals) & 0.15 & 0.09 \\
\hline Plant and machinery (telecommunications) & 0.15 & 0.13 \\
\hline Pre-packaged software & 0.25 & 0.55 \\
\hline Custom software & 0.25 & 0.33 \\
\hline$R \& D$ for motor vehicle manufacturing & 0.25 & 0.31 \\
\hline R\&D for electronic product manufacturing & 0.25 & 0.40 \\
\hline
\end{tabular}

Note: Estimates of true economic depreciation rates have been constructed by converting estimated useful lives provided in India's Companies Act 2013 to declining balance depreciation rates based on Fraumeni (1997) and US Department of Commerce (2003) and Li (2012).

Source: Thomas et al., forthcoming.

\section{Area-based tax relief (backward areas and Special Economic Zones): mixed results}

Generous tax incentives are granted for companies operating in Special Economic Zones (Box 6). Units operating in a special economic zone (SEZ) are fully exempt from corporate income tax for five years, receive a 50\% exemption for the next five years and a further $50 \%$ exemption is provided for another five years to profits that are derived from exports if re-invested. Similar tax concessions apply to developers of SEZs. Recent empirical analysis, however, suggests that these tax concessions have had no clear impact on aggregate investment and exports (Rao et al., 2016). Total employment in SEZs, 1.2 million persons, is low despite the high level of investment. There is also evidence that SEZs may be misused by companies (James, 2013).

\section{Box 6 Special Economic Zones in India}

India was one of the first in Asia to recognise the effectiveness of the Export Processing Zone (EPZ) model in promoting exports, with Asia's first EPZ set up in Kandla (Gujarat) in 1965. The Special Economic Zones (SEZs) Policy was announced in 2000, supported by quality infrastructure, an attractive tax package, both at the central government and the State level, with the minimum possible regulations. The main objectives of the SEZ Act passed in 2005 are:

1. generation of additional economic activity

2. promotion of exports of goods and services;

3. promotion of investment from domestic and foreign sources;

4. creation of employment opportunities;

5. development of infrastructure facilities.

Tax incentives in SEZs include: duty free import; $100 \%$ income tax exemption on export income for SEZ units for first 5 years, $50 \%$ for next 5 years thereafter and $50 \%$ of the ploughed back export profit for next 5 years; exemption from Central Sales Tax; exemption from Service Tax; and exemption from State sales tax and other levies as extended by the respective State Governments.

SEZs employ about 1.2 million people and exports from SEZs accounted for about one fourth of total India's merchandise exports in FY 2013/14.

Source: Government of India, http://www.sezindia.nic.in/ 
Several measures have been taken to reduce tax concessions granted to SEZs but more should be done. Since 2012, units operating in a SEZ are subject to the MAT and the dividend distribution tax. The 2016/17 Budget introduces a sunset clause: tax benefits for SEZs will apply only to those units that begin production before April 2020. This is a welcome initiative but still implies tax relief for companies starting operation in 2020 up to 2030. An earlier sunset should be considered.

Generous tax relief is granted for companies operating in backward states so as to increase investment, employment and output in these regions. Companies operating in these states pay no corporate income tax for the initial five years and a reduced rate for the next five years. Initially designed for North Eastern states, this tax relief was later extended to Jammu and Kashmir in 2002, to Himachal Pradesh and Uttarakhand in 2003. Concessions are granted to a backward state for a 10 year period, and a company commencing operation within this 10-year window benefits from the tax concession for the subsequent 10 years. In addition, an investment and a depreciation allowance were granted to Andhra Pradesh and Bihar in 2016. Rao et al. (2016) found evidence that tax concessions for backward states have raised investment, value added and employment in some backward states, but not in all. This suggests that the overall business environment, and in particular labour and product market regulations as well as infrastructure and human capital, play an important role in raising productivity in the states. To improve the effectiveness of tax concessions for operating in backward states by the central government, their renewal should be made conditional on states' action to improve the overall business environment.

\section{Tax concessions for infrastructure and scientific research: only a second best?}

Tax concessions for developing and operating key infrastructure account for about one fourth of total corporate income tax revenue foregone. They apply to the generation, transmission and distribution of electricity, for telecommunication infrastructure, roads, bridges or rail systems, highway projects, oil and natural gas, as well as some housing projects. In a number of cases, these concessions effectively prop up business profits as prices are set below market prices (e.g. electricity). These concessions have been particularly open to dispute and abuse because of complex eligibility criteria. As an example, size limits on apartments in housing projects have reportedly been bypassed with family members purchasing adjacent apartments to form a large one. Given India's need for better infrastructure and the fragile financial situation of many infrastructure companies, these concessions cannot be scrapped in the short run. Their impact should be assessed regularly; sunset clauses should apply and eligibility criteria should be simple and defined so as to avoid too large a distortion. Improving infrastructure in the longer run would require implementing a price setting process which allows investors, providers and distributors to make "normal" profits, instead of a loss as is currently the case for many of them.

Tax concessions for research and development (R\&D) have been made less generous. The 2016/17 Budget reduced the rate at which companies are allowed to deduct their in-house spending from 200 to $100 \%$. However, the immediate deductibility of capital R\&D expenditure (excluding land and buildings) remains concessionary. Many OECD countries have R\&D tax incentives aimed at increasing private R\&D expenditure towards a socially optimal level that takes account of positive knowledge spill-overs. In India, spending on R\&D is lower than in OECD countries and China but is higher than in Indonesia and South Africa.

Experience in OECD countries suggests that tax incentives can be effective at raising R\&D but the design of such schemes warrant attention in order to minimise the cost to taxpayers and the tendency of such policies to favour less dynamic incumbents at the expense of dynamic young firms (Andrews and Criscuolo, 2013). As in OECD countries, there has also been much debate in India about the effectiveness of tax incentives in raising R\&D spending (Mani, 2010). Rao et al. (2016) point to some evidence of an economy-wide relationship between the increase in $R \& D$ expenses and patents but note that there is little evidence suggesting that companies investing in R\&D saw their performance improve. In addition, R\&D 
concessions are prone to abuse, in particular because what constitutes $R \& D$ expenditure is not obvious and requires significant resources to police. India should thus regularly assess whether remaining $R \& D$ tax concessions are well-designed and are the best instrument to boost R\&D spending.

\section{The taxation of SMEs: reducing disincentives to grow and to incorporate}

Small and medium-sized enterprises (SMEs) account for the bulk of Indian enterprises and bringing more of them into the tax net would have many benefits. It would raise more tax revenue, promote a level playing field and a culture of compliance. It would also improve SMEs' performance by enabling better access to finance and technology and by reducing exposure to harassment from tax inspectors and corruption.

The different regimes for taxing SMEs create distortions against incorporated firms, as well as disincentives to grow. Incorporated SMEs are subject to a combined statutory tax rate ranging between $33.1 \%$ (when the firm does not distribute dividends and faces a 7\% surcharge) to $43.6 \%$ (when all profits are distributed). Income from unincorporated SMEs is taxed under the personal income tax regime at a maximum marginal tax rate of $35.1 \%$ (i.e. $30 \%$ top rate, plus the $15 \%$ surcharge for top incomes and the $2 \%$ education cess), creating a bias against incorporation or growth up to a rather high income threshold. Higher compliance costs typically associated with incorporation add another disincentive to incorporation.

India also applies two presumptive tax regimes for specific unincorporated SMEs. The first one applies to firms in the transport sector owning less than 10 goods carriages. The second presumptive regime applies to firms outside the transport sector with an annual turnover of less than INR 20 million (about USD 312 000). For these firms, the taxable income is set at 8\% of their turnover and personal income tax rates apply. Compared to the various other countries using presumptive taxes based on turnover, the threshold for the presumptive tax is high and the $8 \%$ share of turnover treated as taxable is low (Thomas et al., forthcoming). For those firms operating in sectors where the typical profit margin is above $8 \%$, the system also creates a strong disincentive to increase their (declared) turnover beyond INR 20 million because of the steep increase in tax liability associated with the move to the general corporate income tax system.

A number of reforms should be considered to make the tax system more conducive to SME creation and growth and to encourage tax compliance:

- Efforts to simplify tax compliance, including e-taxation, should be continued.

- A swift and full implementation of the gradual reduction of the corporate tax rate from 30 to $25 \%$ (together with the removal of most tax concessions) will reduce disincentives towards incorporation.

- For presumptive tax regimes, more consideration should also be given to the relevant profit margins (currently $8 \%$ for all enterprises), with potential adjustments over time and across sectors, as is the case in Brazil and France, to more closely reflect the different profit margins of different sectors. This approach has the benefit of aligning better taxable profits with real profits but it also makes the system more complex. To create a smooth path from this regime to the general corporate income tax, eligibility to presumptive taxation could be calculated based on an average of several years. Alternatively, India could follow Mexico in giving firms entering the general corporate income tax system a temporary and graduated reduction in their tax liabilities. 
- To encourage formalisation of small and micro-enterprises, tax compliance could guarantee access to specific public services. In Colombia, the 2010 Formalisation and Job Creation Law embodied reduced tax and social security contributions for some years; simplified administrative and legal procedures; and guaranteed access to government support programmes, including microcredit and training (OECD, 2013).

\section{International considerations: attracting foreign investors while addressing base erosion and profit shifting}

The relatively high corporate income tax rate has made it difficult for India to attract foreign investment. Whether investing via an Indian-resident subsidiary or a (non-resident) branch, a significantly higher tax burden will be borne on repatriated income as compared to most alternative investment destinations. If a foreign investor operates through an Indian-resident subsidiary, s/he will pay an effective corporate tax rate of $34.6 \%$ (30\% statutory rate, plus $12 \%$ surcharge and $3 \%$ cess). In addition, s/he will pay the dividend distribution tax on dividends to the parent company, increasing the total tax rate on repatriated income to $45.9 \%$, much higher than for investment via a subsidiary in most other G20 countries (Figure 6.A). For countries that exempt foreign dividend income, this will be a final tax. For countries that do tax foreign dividend income, the difference can be even larger as the dividend distribution tax may not necessarily be creditable against tax due in the investor's home country, whereas a traditional withholding tax on dividend distribution to a non-resident parent company typically will be (as the dividend distribution $\operatorname{tax}$ is a tax on the resident company rather than the foreign investor).

If a foreign investor operates in India through a branch, s/he will pay the higher $40 \%$ non-resident corporate income tax rate. The higher non-resident corporate income tax rate was introduced when India moved from an imputation system to the current dividend distribution tax so as to provide broad parity between the taxation of distributed dividends of foreign-owned branches and domestic or foreign-owned subsidiaries. Adding the 5\% surcharge and 3\% cess will bring the effective tax rate to $43.3 \%$ for the foreign investor (Box 7).

\section{Box 7 Tax rate calculations for resident and non-resident corporations}

The table below presents a calculation of the tax due on INR 100 of profit earned by an Indian resident vs nonresident corporation with a taxable income of more than INR 100 million (USD 1.56 million), so that the highest surcharge is applicable. For a resident corporation, the after corporate tax profit (INR 65.39) is assumed to be distributed to the shareholder(s) so that the dividend distribution tax (DDT) and associated surcharge and cesses are also payable by the corporation in India.

Table 6 Tax rate for a resident versus a non-resident corporation

\begin{tabular}{|c|c|c|}
\hline (INR) & Resident corporation & Non-resident corporation \\
\hline Corporate income & 100.00 & 100.00 \\
\hline CIT rate & 30.00 & 40.00 \\
\hline Surcharge on CIT at $12 \%$ & 3.60 & 2.00 \\
\hline Education cess on CIT \& surcharge at $2 \%$ & 0.67 & 0.84 \\
\hline Higher education cess on CIT \& surcharge at $1 \%$ & 0.34 & 0.42 \\
\hline DDT at $15 \%$ on distributed dividend & 9.81 & .. \\
\hline Surcharge on DDT at $12 \%$ & 1.18 & .. \\
\hline Education cess on DDT \& surcharge at $2 \%$ & 0.22 & .. \\
\hline Higher education cess on DDT \& surcharge at $1 \%$ & 0.11 & .. \\
\hline Total tax paid & 45.92 & 43.26 \\
\hline
\end{tabular}

Source: Thomas et al. (forthcoming). 
The high statutory rates, combined with the complexity of Indian tax laws and the uncertainty in their interpretation, has weighed on foreign direct investment (FDI). FDI as a share of GDP has increased steadily since the launch of the Make in India campaign but remained lower than in some other emerging economies (Figure 6.B). To increase India's attractiveness, the dividend distribution tax should be replaced in the short term by a traditional withholding tax system and the non-resident corporate income tax rate should be lowered to the resident rate. South Africa undertook such a reform in 2012: the "secondary tax on companies" that was paid on all distributed dividends was replaced by a dividend tax which is paid by individuals and foreign shareholders (but may be reduced by tax treaties). Simultaneously, tax rates for foreign firms were lowered to the standard rate (of 28\%). In the longer term, India could move back to an imputation system which would allow the imposition of progressive personal income tax rates on distributed dividends to domestic personal shareholders. Imposing dividends at the individual rather than corporate level will, however, raise collection costs. A dividend tax imposed on individuals may also be easier to avoid, especially if the HUF system is maintained.

India needs to adjust its tax system to mitigate the risk of revenue losses through multinational companies exploiting mismatches in tax rules. The OECD estimated that the net tax revenue loss from tax planning is 4-10\% of global corporate tax revenues (OECD, 2015c). Such "base erosion and profit shifting" (BEPS) activities are of particular concern for emerging economies (Criveli et al., 2015) which typically rely to a large extent on corporate income tax revenue. India's vulnerability has increased in recent years with the greater openness to trade and FDI. As noted above, international dividend payments from India are subject to the highest combined statutory rate amongst G20 countries, with a more than 10 percentage point difference in most cases. Multinational enterprises (MNEs) investing in India may thus be able to obtain substantial benefits by shifting profits out of India. 
Figure 6 International aspects for the corporate income tax

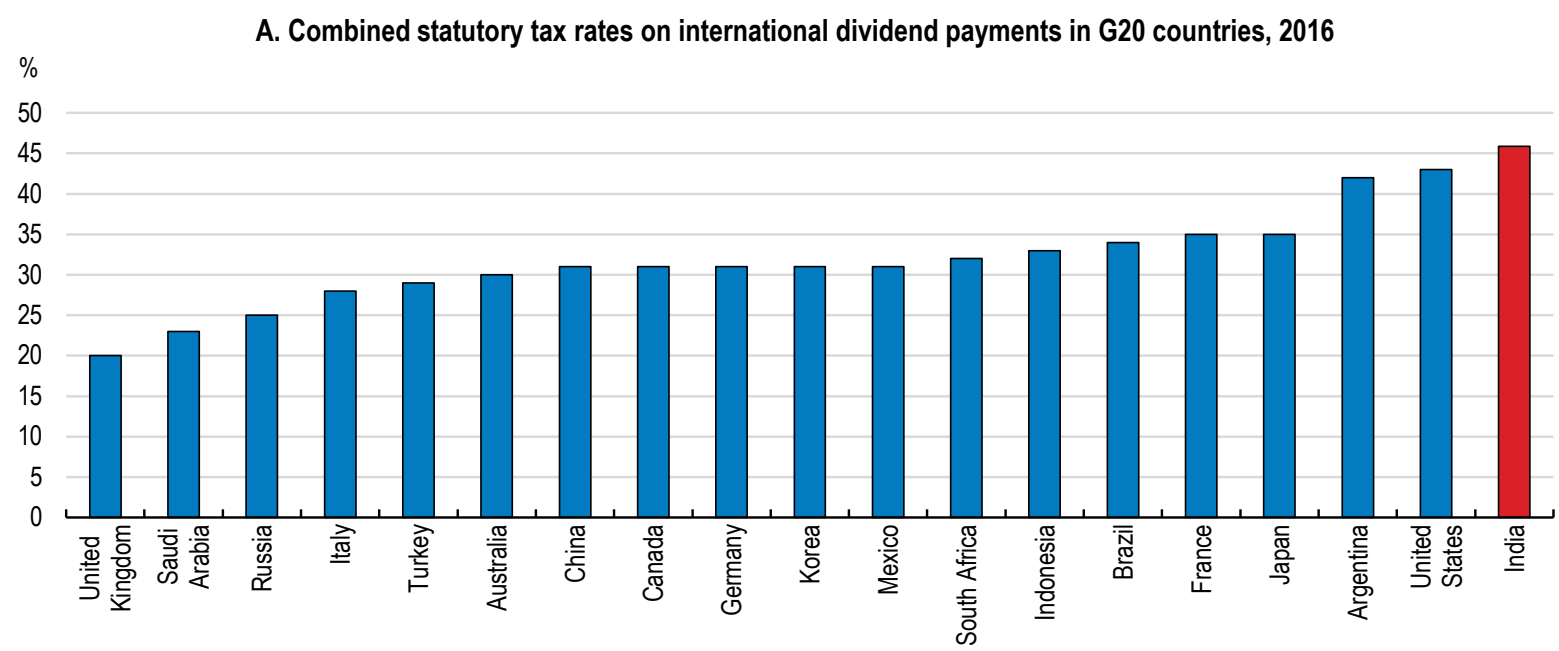

B. FDl inflows in G20 countries, 2015

$\%$ of GDP

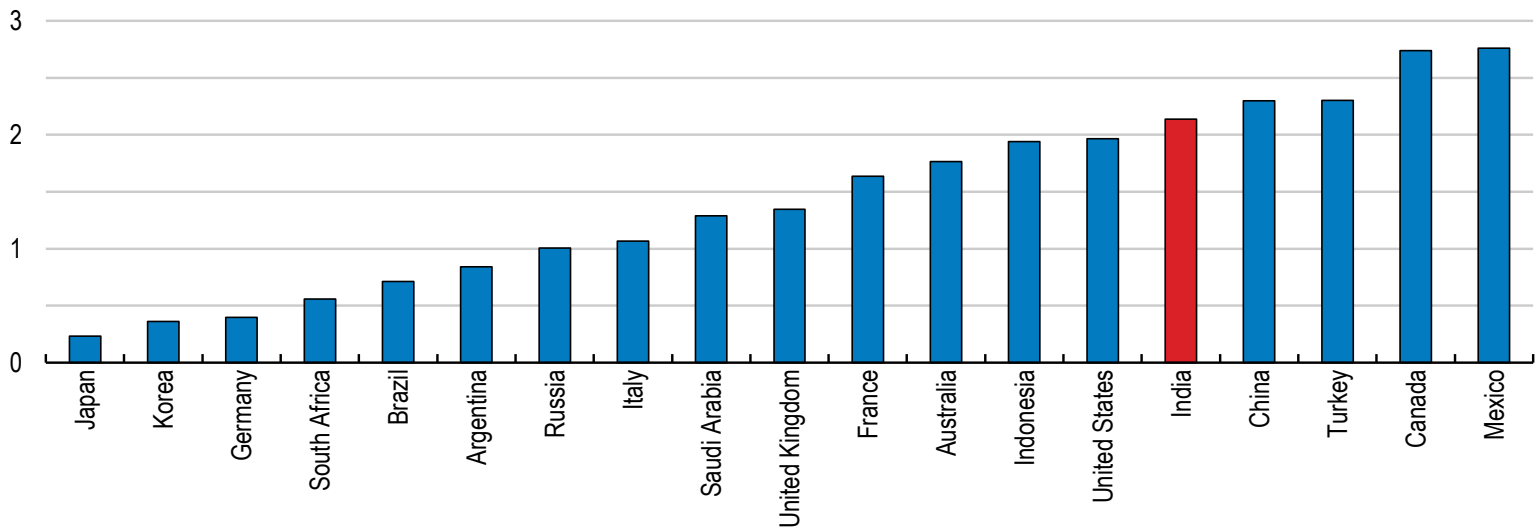

1. Foreign source income is assumed to be exempted in the residence countries. For India, the $45 \%$ rate comprises the $30 \% \mathrm{CIT}$ rate on corporate profits, plus $12 \%$ surcharge on CIT and 3\% cess (on CIT and surcharge amount), plus the $15 \%$ dividend distribution tax.

Source: Reserve Bank of India; Thomas et al. (forthcoming); Brazilian Central Bank; and OECD FDI main aggregates database.

International concern regarding BEPS resulted in the launch of the OECD/G20 BEPS project in 2013 and agreement in 2015 on a package of measures to help equip governments with the domestic and international instruments needed to tackle BEPS (Box 8). India has participated fully in the BEPS project and has agreed to implement the minimum standards agreed in the BEPS package. As part of continuing efforts to boost transparency by MNEs, India also signed the Multilateral Competent Authority agreement for the automatic exchange of Country-by-Country reports.

To improve certainty for foreign investors following recent tax disputes, several measures have been taken. First, the government announced in 2014 that no further retrospective legislation adverse to taxpayers will be introduced. Second, in respect of the existing retrospective amendment regarding the taxation of indirect transfers, the government has set-up a high-level committee to determine the appropriateness of the application of the retrospective legislation on a case-by-case basis. Third, the government has provided legislative clarity that the minimum alternate tax (MAT) will not apply to nonresident corporations/ entities that do not have a permanent establishment in India. 


\section{Box 8 A comprehensive package of measures to address BEPS}

The OECD/G20 BEPS project produced a comprehensive package of measures to address BEPS, including minimum standards, common approaches, best practices and new guidance in the main policy areas:

- Minimum standards have been agreed upon in the areas of fighting harmful tax practices (Action 5), preventing treaty abuse (Action 6), Country-by-Country Reporting (Action 13) and improving dispute resolution (Action 14). All participating countries are expected to implement these minimum standards and implementation will be subject to peer review.

- A common approach, which will facilitate the convergence of national practices by interested countries, has been outlined to limit base erosion through interest expenses (Action 4) and to neutralise hybrid mismatches (Action 2).

- Best practices for countries which seek to strengthen their domestic legislation are provided in the building blocks for effective CFC rules (Action 3 ) and mandatory disclosure by taxpayers of aggressive or abusive transactions, arrangements or structures (Action 12).

- $\quad$ The permanent establishment (PE) definition in the OECD Model Tax Convention has been changed to restrict inappropriate avoidance of tax nexus through commissionaire arrangements or exploitation of specific exceptions (Action 7). In terms of transfer pricing, important clarifications have been made with regard to delineating the actual transaction, and the treatment of risk and intangibles. More guidance has been provided on several other issues to ensure that transfer pricing outcomes are aligned with value creation (Actions 8-10).

- $\quad$ The changes to the PE definition, the clarifications on transfer pricing, and the guidance on CFC rules are expected to substantially address the BEPS risks exacerbated by the digital economy. Several other options, including a new nexus in the form of a significant economic presence, were considered, but not recommended at this stage given the other recommendations plus Value Added Taxes (VAT) will now be levied effectively in the market country facilitating VAT collection (Action 1).

- A multilateral instrument will be implemented to facilitate the modification of bilateral tax treaties (Action 15). The modifications made to existing treaties will address the minimum standards against treaty abuse as well as the updated PE definition. India has agreed to participate in the ad-hoc group that developed the multilateral instrument in 2016.

Source: Thomas et al. (forthcoming).

Efforts to prevent tax treaty abuse should continue to be a top priority. India's treaty with Mauritius, effective since 1983, was of particular concern until recently - Mauritius accounts by far for the largest share of incoming FDI in India (Table 7). Since Mauritius does not tax the capital gains which corporations realise on their assets including shareholdings, a clear tax avoidance strategy consisted of investing in Indian listed companies via a shell company incorporated in Mauritius. While this strategy was obviously attractive for investors from outside India, frequent concerns were raised that Indian companies were also funnelling money through Mauritius and back to India to avoid paying domestic taxes (i.e. so-called 'round tripping'). In May 2016, the treaty was renegotiated and India will get the right to tax capital gains channelled through Mauritius from April 2017. In addition to the case of Mauritius, India currently has tax treaties with around 90 countries. However, many of these treaties were concluded more than a decade ago and do not contain any anti-abuse provisions. Therefore, India's effective implementation of the BEPS Project Action 6 "minimum standard" will be crucial to preventing treaty abuse. 
ECO/WKP(2017)21

Table 7 FDI inflows to India

\begin{tabular}{lccc}
\hline & \multicolumn{2}{c}{2014} & \\
\hline WDI positions & (mn USD) & $\begin{array}{c}\text { Equity positions } \\
\text { (net, mn USD) }\end{array}$ & $\begin{array}{c}\text { Debt positions } \\
\text { (net, mn USD) }\end{array}$ \\
\hline Mauritius & $\mathbf{3 4 2} \mathbf{6 5 3}$ & $\mathbf{3 0 5} \mathbf{5 1 7}$ & $\mathbf{1 9 1 3 7}$ \\
\hline United States & 72967 & 69393 & 3574 \\
\hline United Kingdom & 53343 & 53164 & 179 \\
\hline Singapore & 47364 & 46702 & 662 \\
\hline Japan & 32325 & 27508 & 4817 \\
Germany & 26386 & 24443 & 1943 \\
\hline Netherlands & 25294 & 23922 & 1372 \\
Switzerland & 16248 & 14817 & 1431 \\
Korea & 16119 & 15791 & 328 \\
France & 5440 & 3547 & 1893 \\
\hline
\end{tabular}

Source: IMF Coordinated Direct Investment Survey (CDIS).

Multinational companies can also minimise their worldwide tax liabilities by assigning debt to high-tax locations, such as India, in order to deduct interest payments from profits made in these locations. The literature suggests that the strategic location of debt is one of the quantitatively more relevant tax avoidance techniques (OECD, 2015c). For India, Rao and Sengupta (2014) provide evidence that non-domestic firms pay more interest, and show a higher level of interest payment for any given level of borrowing when compared to domestic firms. To limit debt shifting, India should introduce a fixed ratio rule above which the interest deduction will be disallowed, as recommended in the BEPS Action 4 report.

\section{There is scope to improve the effectiveness of the tax administration and increase compliance}

Several measures have recently been taken to reduce tax evasion. The 2015 bill to tackle "black money" - unaccounted money on which tax has not been paid - embodies severe penalties for not filing returns or for filing returns with inadequate asset and income disclosure. Efforts have also been made to reduce the amount of cash transactions, a common feature in the real estate sector where buyers want to minimise the stamp duty. In November 2016, the government announced that larger banknotes -- INR 500 and 1000 (USD 7.5 and 15) - would cease to be legal tender (demonetisation). The Tax Department made the quoting of the Permanent Account Number (PAN) mandatory for all transactions above INR 0.2 million and, in July 2016, the Supreme Court-constituted special investigation team recommended a ban on cash transactions above INR 0.3 million (around USD 4 700) and a upper limit for cash holdings of INR 1.5 million.

There is scope to enhance revenue performance while reducing compliance and collection costs. Various versions of simplified income tax returns have been introduced since 2015, in an attempt to reach a fine balance between reducing compliance costs and getting enough details to discourage tax evasion. The government is gradually moving towards a paperless tax assessment system, replacing physical visits by email exchanges, with pilots in five large cities. Efforts are also being made to better exploit tax and non-tax information available to the administration by implementing a unique identification number for individuals (Aadhaar) and for enterprises (PAN) which would allow better connecting databases. 


\section{Increasing certainty regarding tax rules and their application}

The proliferation of tax concessions and the 2012 amendment to the Income Tax Act which allowed retrospective taxation, together with aggressive audit activity, have raised uncertainty and costs for both investors and the tax administration. The lack of clarity of the Income Tax law, which uses opaque concepts such as "reasonable", "opinion" and "public interest", sets the stage for chronic battles (Shah, 2015). The number of disputes between the tax administration and taxpayers is large (Figure 7) and the recovery of tax arrears is low. In addition, around $40 \%$ of tax disputes go through the court system and many of them have been in process for several years. In October 2015, the government announced that it is preparing a roadmap to reduce the number of tax-related litigations. Recent efforts to clarify tax rules (e.g. on the taxation of companies which are part of a consortium in large infrastructure projects or on Minimum Alternate Tax for foreigners) and to abolish tax concessions are welcome. These efforts should be pursued as making tax rules clearer and more certain will help boost investment and growth.

Figure 7 Unfinalised tax disputes in India, BRIICS and OECD countries

2012-13

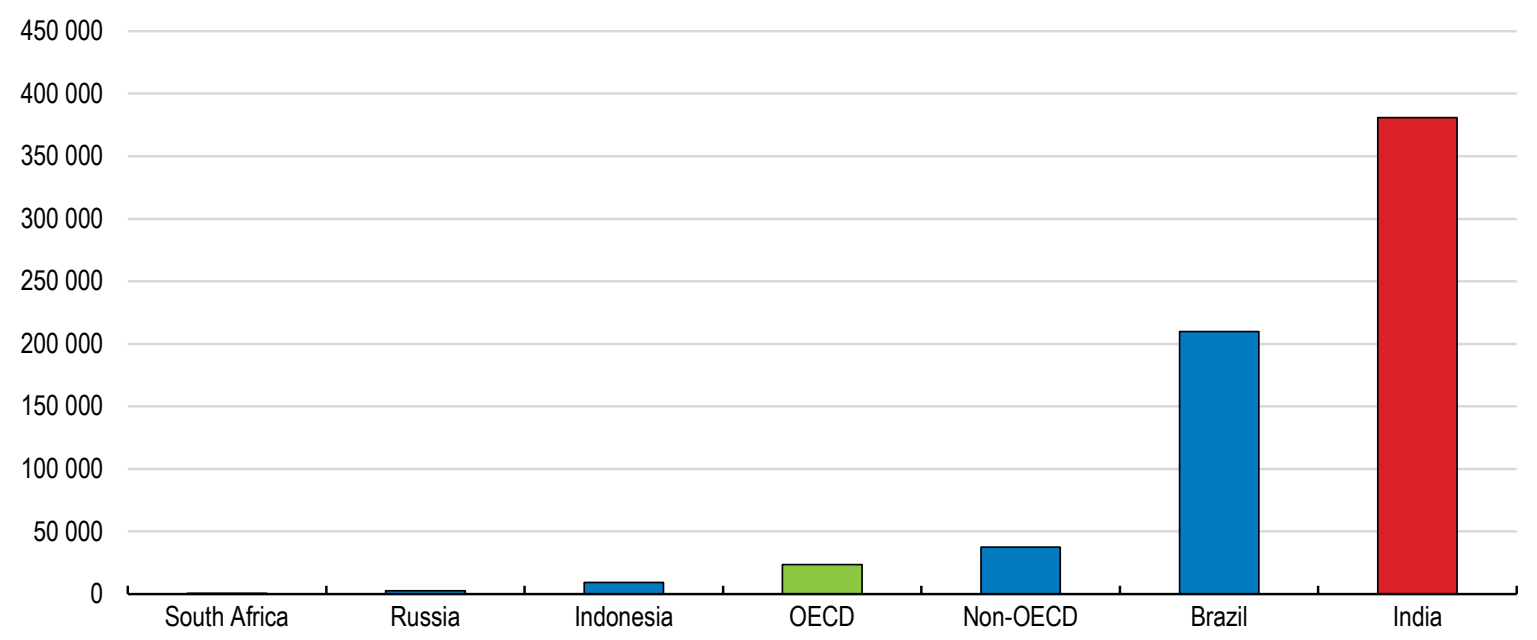

1. "Non-OECD" is an average of 18 non-OECD countries for which data are provided in OECD (2015d).

Source: TARC (2014), drawing on CBDT and CBEC data, and OECD (2015d), Tax Administration 2015: Comparative Information on OECD and other advanced and emerging economies; Indian Ministry of economics.

The low appeal success rate by the tax department further suggests that too many audit cases result in a dispute and, following a decision by the commissioner in the taxpayer's favour, too many cases with limited merit are brought by the Tax Department before the Courts (Thomas et al., forthcoming). The government recently decided not to appeal against the high court ruling providing relief to several companies which were contesting notices issued by the Income Tax Department. Dispute resolution procedures have also been recently expanded. For example, the Authority for Advance Rulings (AAR), which was only available in international tax matters, had its scope extended to some categories of resident taxpayers and two additional benches of the AAR were created in 2015 (one in Mumbai and the other in Delhi).

Improving the audit process would help reduce the number and length of disputes. Some measures have recently been taken, including an increased use of third-party data and risk-based analysis to inform audit strategies. The computerisation of the dispute management process has also increased. However, the combination of limited staffing and expertise in particular audit areas (due partly to staff rotation), the lack 
of clear guidelines in many areas, a fear of corruption accusations and the use of audit revenue targets create strong incentives for assessing officers to take a highly defensive approach towards assessments. The imposition of sanctions against assessing officers who are considered by the Comptroller and Auditor General to have under-assessed incentivises a defensive approach towards assessments. The introduction of a hierarchy of approval in cases where assessments are particularly taxpayer friendly may help to reduce fears of corruption allegations.

India has successfully introduced an advance pricing agreement (APA) programme into its transfer pricing regime. Under the programme, a taxpayer can apply for an APA prior to a proposed transaction taking place, thereby providing certainty as to the taxpayer's transfer prices and avoiding potential future disputes with the tax administration. The APA programme has proved very popular - with more than 700 APA applications filed as of $30^{\text {th }}$ August, 2016 (Government of India, 2016b). The greater use of bilateral rather than unilateral APAs, so as to reduce the risk of double taxation and better ensure that APAs are equitable to all tax administrations and taxpayers involved, would be a positive step.

\section{Increasing the overall capacity of the tax administration}

The tax administration workforce should be expanded to raise revenues. Staff numbers have not increased significantly in the past 10 years, despite an expanding tax base and consequent increased workload. They stand considerably below the level in other countries (Figure 8.A), with consequences for performance. For example, as a result of the increased workload, the percentage of cases selected for scrutiny in the Central Board of Direct Taxes has decreased from 8\% in 1997-98 to around 1.25\% in 2011-12 (Prasanth, 2013). International comparisons reveal that India spends significantly less on tax administration (Figure 8.B). Anecdotal evidence suggests that the education level of employees and on-thejob-training below senior levels is a problem. To overcome it, the Tax Administration Review Commission (TARC) recommended that $10 \%$ of expenditure be spent on staff training, against less than $1 \%$ currently (Box 9).

One area that India has prioritised is the adoption of information technology, with $12 \%$ of total tax administration expenditure spent on it in 2013 (Figure 8.D). As a result, about 95\% of tax filings at the central government level are electronic and refunds are issued in about a week (Government of India, 2016a, Chapter 7). In 2013, $80 \%$ of all personal income tax returns were e-filed, up from $17 \%$ in 2009 , while the average in OECD countries is $72 \%$ (OECD, 2015d). Significant progress with e-taxation has also been made at the state level. Among the 98-points of the action plan for business reform agreed by state governments in December 2014, implementation of tax reform has been the fastest. Most states now allow on-line payment and return filing for various taxes. 
Figure 8 Tax administration capacity in India is comparatively low

A. Citizens per tax administration employee Citizens

35000

30000

25000

20000

15000

10000

5000

0

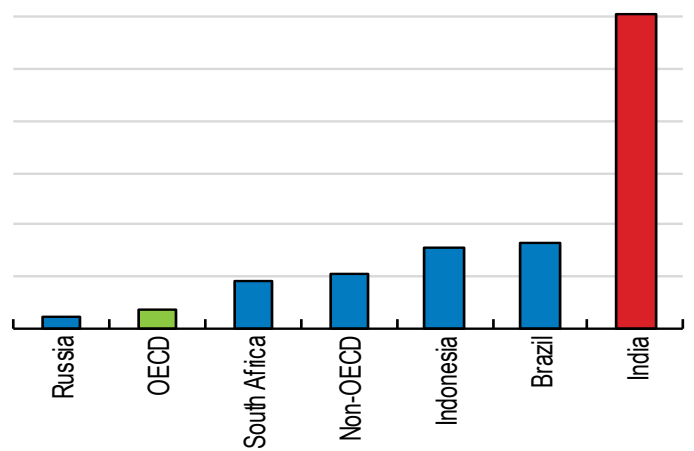

C. HRM expenditure/tax administration

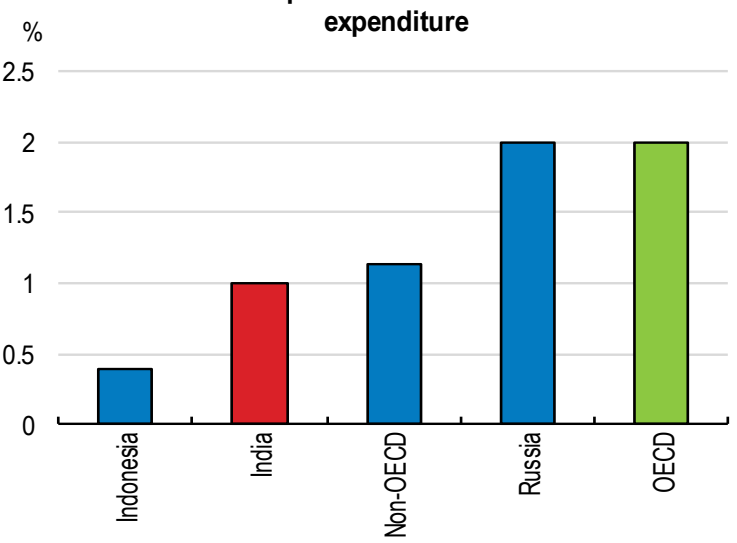

B. Tax administration expenditure/GDP $\%$ of GDP

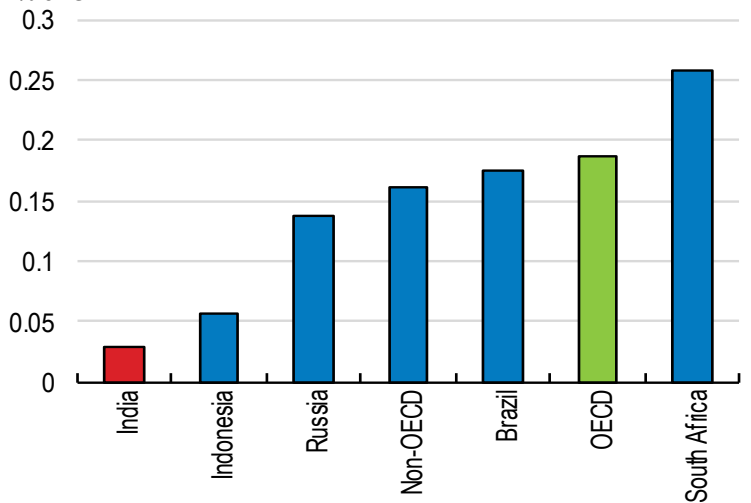

D. IT expenditure/tax administration expenditure

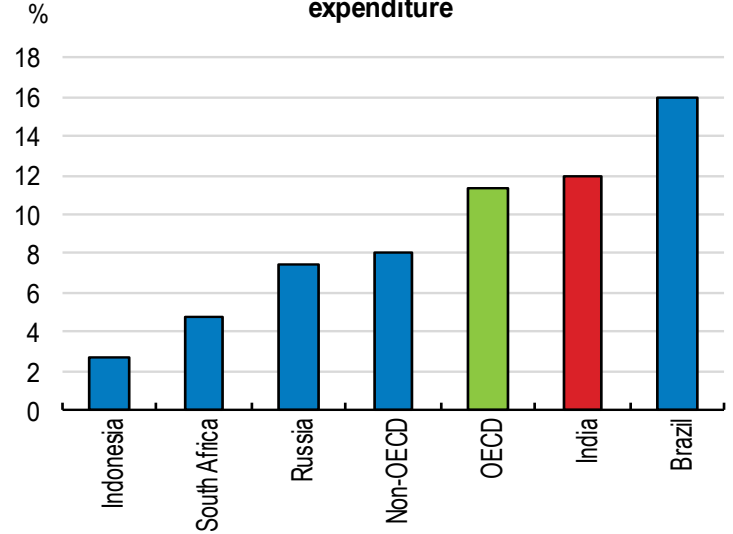

1. Data for India only relates to the CBDT.

2. Non-OECD is an average of 18 non-OECD countries for which data are provided in OECD (2015d).

Source: OECD (2015d), Tax Administration 2015: Comparative Information on OECD and other advanced and emerging economies. 


\section{Box 9 Key recommendations of the Tax Administration Review Commission (TARC)}

The Tax Administration Reform Commission (TARC) was set up in 2013 to provide recommendations for improving the effectiveness of the tax administration. The TARC proposed modernising the tax administration, in particular moving the culture of the administration towards more customer services and away from the current adversarial culture. Key recommendations from the TARC reports are summarised below:

- Improving coordination between the Central Board of Direct Taxes (CBDT) and the Central Board of Excise and Customs (CBEC) and integrating the two bodies in 10 years. This recommendation has not been accepted as the CBDT and CBEC have distinct domain knowledge, expertise and skill sets. Both are however taking steps to better share data and information and to exploit synergies in policy formulation.

- Relying more on information technology and integrated databases. In particular, pre-filled tax returns should be provided to all individuals.

- Increasing specialisation of tax officers. Raising the quality of tax administration professionals through skill development.

- Minimising the potential for disputes by issuing clear and lucid interpretative statements on contentious issues. This recommendation has been accepted by the government.

- $\quad$ Dispute resolution processes should be reformed to be faster, less adversarial, more collaborative and customer focused.

- Avoiding retrospective amendment of tax legislation. This recommendation has been accepted by the government and the Finance Minister categorically stated that retrospective amendments will be avoided.

- $\quad$ Creating an advisory tax policy unit, advisory in nature. This recommendation was followed by the creation in February 2016 of a Tax Policy Council headed by the Finance Minister as well as a tax policy research unit. 


\section{Recommendations for reforming direct taxes}

\section{Key recommendations}

- Implement fully the gradual reduction of the corporate income tax rate from $30 \%$ to $25 \%$ together with the removal of most tax incentives.

- Gradually increase the number of taxpayers in the personal income tax system by keeping the basic exemption thresholds constant in nominal terms for several years, by treating agricultural income as any other income and by engaging in a communication campaign to raise civic engagement and tax compliance.

- Keep the upper personal income tax threshold constant in nominal terms and reconsider personal income tax concessions which benefit the rich most (in particular those related to housing investment) to gradually raise tax progressivity.

- Enable local governments to raise more revenue from recurrent taxes on immovable property by granting them more, and more certain, taxing powers and by supporting the updating of property registries.

- Secure the corporate tax base by swiftly implementing the BEPS package.

- Increase clarity in tax legislation and its application and avoid overly aggressive tax audits.

\section{Other recommendations}

\section{Personal and property taxes}

- Move towards a more neutral taxation of personal savings. In particular, pension savings should be taxed at least at one stage.

- Introduce an inheritance tax. This would require reconsidering the Hindu Undivided Family (HUF) system whereby property of an individual becomes property of its family members without being subject to tax at the time of the transfer.

- If more revenue is generated from recurrent taxes on property, lower taxes on property transactions gradually.

- Raise the cap on states' professional tax and eliminate the deductibility from the central government income tax.

- Remove the existing bias against job creation embodied in the social security contribution system by either making contributions mandatory for all workers while abolishing caps, or by eliminating social security contributions and financing social security benefits through general taxation.

\section{Corporate income tax}

- Improve neutrality across various tax regimes to eliminate disincentives for firms to grow. In particular, easing tax compliance further and creating a smooth path from presumptive tax regimes to corporate income tax would help.

- The renewal of corporate income tax concessions for operating in backward states by the central government should be made conditional on states' action to improve the overall business environment.

- Adjust presumptive tax regimes to make them fair and create a smooth path to the general corporate income tax regime. Consider introducing a small, and easy to comply with, lump-sum tax to encourage formalisation of micro-enterprises accompanied by guaranteed access to specific public services.

- Replace the dividend distribution tax with a traditional dividend withholding tax and lower the corporate income tax rate for foreign companies to the resident rate.

\section{Tax administration and legislation}

- Efforts to simplify and clarify tax rules should be pursued so as to reduce compliance and collection costs and to boost investment and growth.

- Increase the number and training of staff employed in the tax administration.

- Improve the audit process by providing guidelines and changing the incentive structure for assessing officers.

- Make dispute resolution mechanisms more effective to reduce the share and shorten the length of unresolved disputes.

- Encourage the use of bilateral Advance Pricing Agreements (APAs) to reduce the risk of double taxation and better ensure that APAs are equitable to all tax administrations and taxpayers involved. 
ECO/WKP(2017)21

\section{REFERENCES}

Andrews, D. and C. Criscuolo (2013), "Knowledge-Based Capital, Innovation and Resource Allocation: A Going for Growth Report", OECD Economic Policy Papers, No. 4, OECD Publishing, Paris. DOI: http://dx.doi.org/10.1787/5k46bh921r35-en

Blöchliger H. (2015), "Reforming the tax on immovable property: taking care of the unloved", OECD Economic Department Working Paper No. 1205, DOI: http://dx.doi.org/10.1787/5js30tw0n7kg-en

Credit Suisse (2015), Global Wealth Databook http://publications.credit-suisse.com/tasks/render/file/index.cfm?fileid=C26E3824-E868-56E0CCA04D4BB9B9ADD5

Crivelli E.; R. A. de Mooij, M. Keen (2015), "Base Erosion, Profit Shifting and Developing Countries", IMF Working Paper No. 15/118 https://www.imf.org/external/pubs/ft/wp/2015/wp15118.pdf

Government of India (2015), National Health Policy 2015 - draft. http://www.mohfw.nic.in/showfile.php?lid=3014

Government of India (2016a), Economic Survey 2015/16. http://indiabudget.nic.in/survey.asp

Government of India, Ministry of Finance (2016b) "Signing of Unilateral Advance Pricing Agreements by CBDT", Press Release, 30 August.

Johansson, Å., C. Heady, J. Arnold, B. Brys and L. Vartia (2008), "Taxation and Economic Growth", OECD Economics Department Working Papers, No. 620, OECD Publishing, Paris. DOI: http://dx.doi.org/10.1787/241216205486

James, S. (2013) "Effectiveness of Tax and Non-Tax Incentives and Investments: Evidence and Policy Implications", Investment Climate Advisory Services, World Bank Group.

Joumard, I., P. Hoeller, J.-M. Fournier and H. Morgavi (forthcoming), "Public debt in India: Moving towards a prudent level?", OECD Economics Department Working Papers, forthcoming, OECD Publishing, Paris.

Joumard,I., M. Pisu and D. Bloch (2012), "Less Income Inequality and More Growth - Are They Compatible? Part 3. Income Redistribution via Taxes and Transfers Across OECD Countries", OECD Economics Department Working Papers, No. 926, OECD Publishing, Paris. DOI: http://dx.doi.org/10.1787/5k9h296b1zjf-en

Mani, S. (2010) "Financing of industrial innovations in India: how effective are tax incentives for R\&D?", International Journal of Technological Learning, Innovation and Development, Vol. 3(2), pp109131.

NIPFP (2015), "Development of an analytical model for widening of taxpayer's base", http://www.nipfp.org.in/media/medialibrary/2015/10/Development_of_an_Analytical_Model_for_ Widening_of_Taxpayers_Base.pdf 
OECD (2012), Going for Growth, Chapter 5 (Reducing income inequality while boosting economic growth: can it be done?), OECD Publishing, Paris.

OECD (2013), Economic Assessment of Colombia.

OECD (2014), OECD Economic Surveys: India 2014, OECD Publishing, Paris. DOI: http://dx.doi.org/10.1787/eco_surveys-ind-2014-en

OECD (2015a), OECD Economic Surveys: South Africa 2015, OECD Publishing, Paris. DOI: http://dx.doi.org/10.1787/eco_surveys-zaf-2015-en

OECD (2015b), Revenue Statistics 2015, OECD Publishing, Paris.

DOI: http://dx.doi.org/10.1787/rev_stats-2015-en-fr

OECD (2015c), Measuring and Monitoring BEPS, Action 11 - 2015 Final Report, OECD/G20 Base Erosion and Profit Shifting Project, OECD Publishing, Paris.

DOI: http://dx.doi.org/10.1787/9789264241343-en

OECD (2015d), Tax Administration 2015: Comparative Information on OECD and Other Advanced and Emerging Economies, OECD Publishing, Paris.

DOI: http://dx.doi.org/10.1787/tax_admin-2015-en

OECD (2015e), "The recurrent tax on immovable property: Guiding principles for reform" COM/CTPA/ECO/GOV(2015)5.

OECD (2015f), Inequality and inclusive growth: policy tools to achieve balanced growth in G20 economies,

https://www.oecd.org/g20/topics/framework-strong-sustainable-balanced-growth/Inequality-andInclusive-Growth-Policy-Tools-to-Achieve-Balanced-Growth-in-g20-Economies.pdf

Piketty T. and N. Qian (2009), "Income Inequality and Progressive Income Taxation in China and India, 1986-2015”, American Economic Journal, Applied Economics, Vol; 1 (2), pp. 53-63.

Piketty, T. (2001), Les hauts revenus en France au 20e siècle : inégalités et redistribution, 1901-1998. Paris: B. Grasset.

Piketty T. and E. Saez (2013), "A theory of optimal inheritance taxation”, Econometrica, September 2013, Vol. 81, Issue 5, pp. 1851-1886.

Prasanth P.S., (2013), "What really ails the income tax department in India", http://www.pressreader.com/india/bureaucracy-today/20130401/281539403420374

Rao R. K. and D. P. Sengupta (2014), "Action Plan on Base Erosion and Profit Shifting -- An Indian Perspective", National Institute of Public Finance and Policy Working Paper No. 2014-133 http://www.nipfp.org.in/media/medialibrary/2014/03/WP_2014_133.pdf

Rao K.R., S. Tandon and S. Mukherjee (2016), "Corporate Tax: A brief assessment of some exemptions" NIPFP Working paper No. 165

Rao G. (2013), "Property Tax System in India: Problems and Prospects of Reform", NIPFP Working Paper No. 114 http://www.nipfp.org.in/media/medialibrary/2013/04/WP_2013_114.pdf

Sanyal A. (1995), "The Hindu Undivided Family: Effects on the Indian Tax System", The Park Place Economist, Vol. 3. 
ECO/WKP(2017)21

Shah A. (2015), "Infrastructure investment in India: Setting up the second wave" http://macrofinance.nipfp.org.in/PDF/13-Gujsl_Shah_second_wave_infrastructure.pdf

TARC (2014) “Tax Administration Reform in India: Spirit, Purpose and Empowerment”, First Report of the Tax Administration Reform Commission, Government of India.

Thomas, A., I. Joumard, T. Hanappi and M. Harding (forthcoming) "Taxation and Investment in India", OECD Economics Department Working Papers.

World Bank (2014), Enterprise Survey, Country Profile, India 2014,

https://www.enterprisesurveys.org/ /media/GIAWB/EnterpriseSurveys/Documents/Profiles/English/ India-2014.pdf 